University of Nebraska - Lincoln

DigitalCommons@University of Nebraska - Lincoln

Vegetation and paleoclimate of the last interglacial period, central Alaska

Daniel R. Muhs

US Geological Survey, dmuhs@usgs.gov

Thomas A. Ager

US Geological Survey, tager@usgs.gov

James E. Begét

University of Alaska

Follow this and additional works at: https://digitalcommons.unl.edu/usgsstaffpub

Part of the Earth Sciences Commons

Muhs, Daniel R.; Ager, Thomas A.; and Begét, James E., "Vegetation and paleoclimate of the last interglacial period, central Alaska" (2001). USGS Staff -- Published Research. 178.

https://digitalcommons.unl.edu/usgsstaffpub/178

This Article is brought to you for free and open access by the US Geological Survey at DigitalCommons@University of Nebraska - Lincoln. It has been accepted for inclusion in USGS Staff -- Published Research by an authorized administrator of DigitalCommons@University of Nebraska - Lincoln. 


\title{
Vegetation and paleoclimate of the last interglacial period, central Alaska
}

\author{
Daniel R. Muhs ${ }^{\mathrm{a}, *}$, Thomas A. Ager ${ }^{\mathrm{a}}$, James E. Begét ${ }^{\mathrm{b}}$ \\ ${ }^{a}$ US Geological Survey, MS 980, Box 25046, Federal Center, Denver, CO 80225 USA \\ ${ }^{\mathrm{b}}$ Department of Geology and Geophysics, University of Alaska, Fairbanks, Alaska 99775-5780 USA
}

\begin{abstract}
The last interglacial period is thought to be the last time global climate was significantly warmer than present. New stratigraphic studies at Eva Creek, near Fairbanks, Alaska indicate a complex last interglacial record wherein periods of loess deposition alternated with periods of soil formation. The Eva Forest Bed appears to have formed about the time of or after deposition of the Old Crow tephra (dated to $\sim 160$ to $\sim 120 \mathrm{ka}$ ), and is therefore correlated with the last interglacial period. Pollen, macrofossils, and soils from the Eva Forest Bed indicate that boreal forest was the dominant vegetation and precipitation may have been greater than present around Fairbanks during the peak of the last interglacial period. A new compilation of last interglacial localities indicates that boreal forest was extensive over interior Alaska and Yukon Territory. Boreal forest also extended beyond its present range onto the Seward and Baldwin Peninsulas, and probably migrated to higher elevations, now occupied by tundra, in the interior. Comparison of last interglacial pollen and macrofossil data with atmospheric general circulation model results shows both agreement and disagreement. Model results of warmer-than-present summers are in agreement with fossil data. However, numerous localities with boreal forest records are in conflict with model reconstructions of an extensive cool steppe in interior Alaska and much of Yukon Territory during the last interglacial. (C) 2000 Elsevier Science Ltd. All rights reserved.
\end{abstract}

\section{Introduction}

The last interglacial period is of considerable interest to both paleoclimatologists and climate modellers because it is thought to be the last time global climates were significantly warmer than present, and is a possible ana$\log$ for future warm climates. During the peak of the last interglacial period around $125 \mathrm{ka}$, sea level was about $6 \mathrm{~m}$ higher than present, based on dating of emergent coral reefs on tectonically stable coastlines distant from plate boundaries (Harmon et al., 1983; Chen et al., 1991; Collins et al., 1993; Muhs et al., 1994). These data indicate that global ice volumes were significantly lower than present, by an amount equivalent to the present volume of the Greenland or West Antarctic ice sheets. Such inferences about lower ice volume are supported by oxygen isotope records in foraminifera found in deep-sea cores, which show strongly negative values during stage $5 \mathrm{e}$, generally interpreted to be the peak of the last interglacial (Martinson et al., 1987). Data from the Vostok ice core of Antarctica indicate that atmospheric carbon

*Corresponding author. Tel.: 1-303-236-7919; fax: 1-303-236-5349. dioxide concentrations were higher than the highest preanthropogenic Holocene levels (Lorius et al., 1985, 1990; Barnola et al., 1991). Pollen data from many northern hemisphere continental records including North America (King and Saunders, 1986; Zhu and Baker, 1995), Europe (Woillard, 1978; Zagwijn, 1996), and Asia (Lozhkin and Anderson, 1995) show significant warming and migration of biomes (relative to present) during the last interglacial .

Of particular interest to paleoclimate modeling is the response of high-latitude regions to global warming during the last interglacial. Such regions are particularly sensitive to climate warming, may respond earliest to external climate forcing, and are important in feedback mechanisms in global climate systems (LIGA Members, 1991). Although the last interglacial is generally believed to have been warmer than present in high-latitude regions (see summary by LIGA Members, 1991), conflicting evidence has been reported for the climate of the last interglacial period in interior Alaska. On the basis of fossil small mammal, insect and pollen data from the Eva Creek locality near Fairbanks, Guthrie (1968) and Matthews (1970) report that tundra was the predominant vegetation during the last interglacial period, although 
tree-sized wood was found in apparent association with the tundra assemblage.

The stratigraphic unit studied by Guthrie (1968) and Matthews (1970) was formalized as the Eva Formation by Péwé (1975b), but is more recently referred to as the Eva Forest Bed (Péwé et al., 1997). Stratigraphic and geochronologic studies by the latter authors indicate that the unit probably does indeed date from the last interglacial period, but the bed contains abundant Picea and Betula (probably B. papyrifera) macrofossils, which indicate a boreal forest much like the present. The conclusions of Péwé et al. (1997) therefore disagree with those of Guthrie (1968) and Matthews (1970).

The presence of a climate as warm or warmer than the present, capable of supporting a boreal forest in interior Alaska during the last interglacial and resulting in considerable thawing of permafrost (Péwé et al., 1997), is consistent with recent atmospheric general circulation model (AGCM) and vegetation reconstructions of the northern hemisphere for the last interglacial (Kutzbach et al., 1991; Harrison et al., 1991; de Noblet et al., 1996; Montoya et al., 1998). These studies show that summer temperatures in coastal Alaska could have been as much as $2^{\circ} \mathrm{C}$ higher than present and as much as $3-4^{\circ} \mathrm{C}$ warmer than present in interior Alaska during the last-interglacial, which certainly could support a boreal forest cover if the warmer temperatures were balanced by sufficient moisture availability. However, although Harrison et al. (1995) presented a vegetation simulation for the last interglacial that showed an expanded boreal forest, relative to the present, in Alaska and northwestern Canada, this same experiment also resulted in the emergence of a considerable area of cool-season steppe in interior Alaska and Yukon. Thus, different approaches have suggested that interior Alaska could have had tundra, boreal forest, cool steppe or some combination of these biomes during the last interglacial period.

In this study we present new stratigraphic, geochronologic, pollen, and soil data from the type locality of the Eva Forest Bed. Although Péwé et al. (1997) presented a comprehensive study of this important deposit, they did not conduct pollen or soils studies. We also present a new compilation of last interglacial vegetation records in Alaska and Yukon, updating the summaries of Hamilton and Brigham-Grette (1991) and LIGA Members (1991), and discuss how these data compare to AGCM results of Harrison et al. (1995).

\section{Methods}

Chronology is based on identification of tephras and radiocarbon dating of wood and humic acids from soil organic matter. Tephras were identified by major-element geochemistry of glass fractions isolated from bulk tephra samples using a microprobe, following the methods outlined by Begét et al. (1991); all data are summarized in Table 1. Comparisons were made to published data on glass chemistry for tephras in interior Alaska reported by Westgate et al. (1983, 1985), Begét et al. (1991), Preece et al. (1992), and Berger et al. (1996). Radiocarbon ages were determined on wood samples or humic acid extractions from organic matter in paleosol A horizons (detailed extraction steps for the latter are in Abbott and Stafford, 1996); ages and laboratory numbers are summarized in Table 2.

Pollen samples reported in this study were collected mostly from thin, discontinuous layers of peat and leaf litter preserved within loess, although a few samples came from non-peaty paleosols and loess. Samples were processed to extract pollen and spores following methods

Table 1

Major element chemistry of glass shards from tephras at Eva Creek. All values in wt pt

\begin{tabular}{|c|c|c|c|c|c|c|c|c|c|c|c|c|}
\hline Tephra (UAF \#) & $n$ & $\mathrm{Na}_{2} \mathrm{O}$ & $\mathrm{MgO}$ & $\mathrm{Al}_{2} \mathrm{O}_{3}$ & $\mathrm{SiO}_{2}$ & $\mathrm{Cl}$ & $\mathrm{K}_{2} \mathrm{O}$ & $\mathrm{CaO}$ & $\mathrm{TiO}_{2}$ & $\mathrm{Fe}_{2} \mathrm{O}_{3}$ & Total & Correlation \\
\hline Tephra 4 (Act 2239) & 33 & 4.56 & 0.6 & 14.16 & 71.73 & 0.13 & 3.49 & 1.91 & 0.57 & 2.85 & 100 & Dome \\
\hline $\mathrm{SD}$ & & $(0.19)$ & $(0.11)$ & $(0.28)$ & $(0.73)$ & $(0.03)$ & $(0.12)$ & $(0.25)$ & $(0.1)$ & $(0.31)$ & & \\
\hline Tephra 4A (Act 2346) & 26 & 4.48 & 0.59 & 14.10 & 71.80 & 0.12 & 3.59 & 1.87 & 0.68 & 2.79 & 100 & Dome \\
\hline $\mathrm{SD}$ & & $(0.31)$ & $(0.09)$ & $(0.32)$ & $(0.81)$ & $(0.06)$ & $(0.21)$ & $(0.13)$ & $(0.15)$ & $(0.25)$ & & \\
\hline Tephra 3 (Act 2237) & 23 & 4.41 & 0.58 & 14.12 & 71.9 & 0.11 & 3.56 & 1.82 & 0.79 & 2.72 & 100 & Dome \\
\hline $\mathrm{SD}$ & & $(0.22)$ & $(0.1)$ & $(0.18)$ & $(0.74)$ & $(0.02)$ & $(0.12)$ & $(0.23)$ & $(0.19)$ & $(0.29)$ & & \\
\hline Tephra 2 (Act 2240) & 31 & 3.95 & 0.3 & 13.1 & 74.96 & 0.32 & 3.83 & 1.41 & 0.3 & 1.81 & 100 & Old Crow \\
\hline $\mathrm{SD}$ & & $(0.14)$ & $(0.04)$ & $(0.27)$ & $(0.32)$ & $(0.03)$ & $(0.11)$ & $(0.06)$ & $(0.08)$ & $(0.15)$ & & \\
\hline Tephra 2A (Act 2345) & 21 & 3.54 & 0.35 & 13.31 & 75.48 & 0.31 & 3.61 & 1.23 & 0.27 & 1.90 & 100 & Old Crow \\
\hline $\mathrm{SD}$ & & $(0.35)$ & $(0.14)$ & $(0.19)$ & $(0.34)$ & $(0.36)$ & $(0.25)$ & $(0.32)$ & $(0.15)$ & $(0.24)$ & & \\
\hline Tephra 2B (Act2345a) & 22 & 3.59 & 0.30 & 13.27 & 75.15 & 0.28 & 3.72 & 1.49 & 0.29 & 1.91 & 100 & Old Crow \\
\hline $\mathrm{SD}$ & & $(0.15)$ & $(0.04)$ & $(0.16)$ & $(0.33)$ & $(0.04)$ & $(0.42)$ & $(0.06)$ & $(0.11)$ & $(0.09)$ & & \\
\hline Tephra 1 (Act 2238) & 19 & 4.31 & 0.72 & 15.9 & 72.34 & 0.05 & 2.1 & 2.41 & 0.23 & 1.92 & 100 & Sheep Creek \\
\hline $\mathrm{SD}$ & & $(0.25)$ & $(0.22)$ & $(0.46)$ & $(0.97)$ & $(0.03)$ & $(0.17)$ & $(0.29)$ & $(0.12)$ & $(0.27)$ & & \\
\hline
\end{tabular}


Table 2

Radiocarbon ages from the Eva Creek area, Fairbanks, Alaska

\begin{tabular}{llll}
\hline $\begin{array}{l}\text { Stratigraphic unit and } \\
\text { sample }\end{array}$ & $\begin{array}{l}\text { Material } \\
\text { dated }\end{array}$ & Laboratory\# & Age (yr) \\
\hline $\begin{array}{l}\text { Organic-rich } \\
\text { upper part }\end{array}$ & $\begin{array}{l}\text { Humic } \\
\text { acids }\end{array}$ & CAMS-24363 & $37,490 \pm 710$ \\
$\begin{array}{l}\text { Organic-rich paleosol, } \\
\text { lower part }\end{array}$ & Salix & CAMS-24364 & $>47,800$ \\
$\begin{array}{l}\text { Eva Forest Bed, wood } \\
\text { sample C }\end{array}$ & Picea & Beta-110125 & $38,820 \pm 990$ \\
$\begin{array}{l}\text { Eva Forest Bed, wood } \\
\text { sample D }\end{array}$ & Picea & Beta-110127 & $>47,080$ \\
$\begin{array}{l}\text { Eva Forest Bed, wood } \\
\text { sample E }\end{array}$ & Picea & CAMS-24380 & $>51,700$ \\
\hline
\end{tabular}

slightly modified from Doher (1980). The percentages of each pollen type found in individual samples were calculated from a pollen sum that included all pollen types found in that sample. The percentages of spore types were calculated from a sum consisting of total pollen plus total spores counted for that sample. A pollen sum of at least 300 grains per sample was achieved for all but one sample studied. In general, preservation of pollen is poor in Alaskan loess deposits. The best recovery of pollen has been achieved in paleosols and peat layers.

Modern soils and paleosols were described in the field and analyzed for organic matter content and selected major element concentrations. For most samples with less than $\sim 7 \%$ organic matter content, the Walkley-Black method was used for estimating organic matter content; for samples with higher organic matter contents, loss on ignition was used (Allison, 1965). Concentrations of major elements were determined by wavelength-dispersive $\mathrm{X}$-ray fluorescence.

\section{Present climate and vegetation of interior Alaska}

The present climate of central Alaska is strongly continental, and temperature regimes in interior Alaska reflect this character (Hare and Hay, 1974). Winters are long and cold, and summers are warm but relatively short. Mean annual air temperature at Fairbanks is $-2.8^{\circ} \mathrm{C}$ and mean July temperature (Fig. 1) is $16.9^{\circ} \mathrm{C}$ (both values are 1961-1990 means). Summer (June, July, and August) is the period when the majority of precipitation occurs. Because of the presence of the Alaska Range to the south, air masses from the north Pacific Ocean lose much of their moisture before penetrating very far inland. As a consequence, much of interior Alaska has annual precipitation totals of only about $250-400 \mathrm{~mm}$; the 1961-1990 mean at Fairbanks is $276 \mathrm{~mm}$ (Fig. 2). The

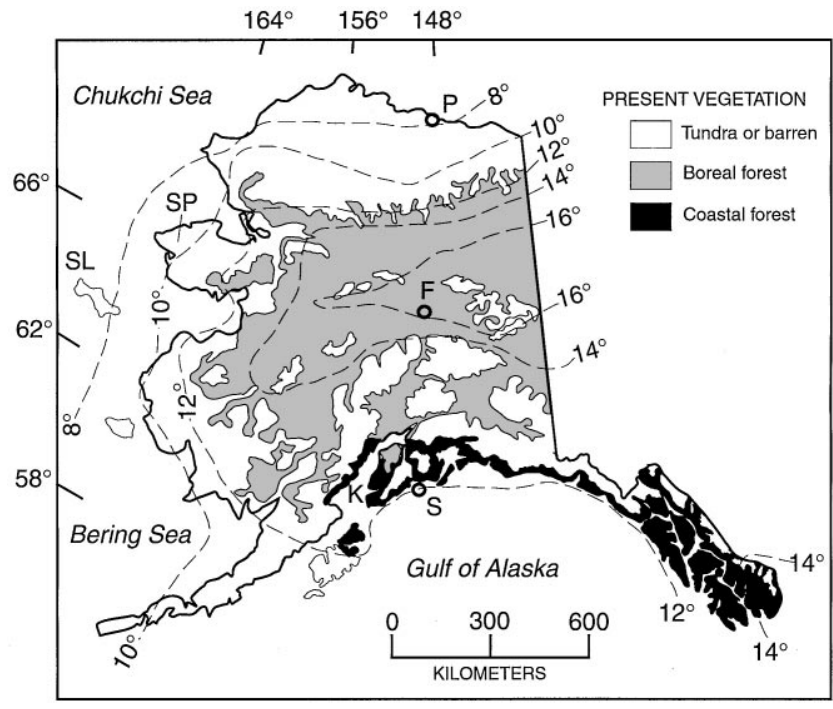

Fig. 1. Map showing the present distribution of vegetation communities in Alaska (from Viereck and Little, 1972 as redrawn by Ager and Brubaker, 1985) and mean July isotherms (mostly 1961-1990 means). Isotherms compiled by the authors. P, Prudhoe Bay; F, Fairbanks; S, Seward; SL, St. Lawrence Island; K, Kenai; SP, Seward Peninsula.

presence of the Brooks Range to the north of interior Alaska has little effect on the precipitation regime because Arctic air masses from the north are relatively dry. We computed potential evapotranspiration (PE) using the Thornthwaite and Mather (1957) method and net moisture (precipitation, or P, minus PE) in a north-south transect from Prudhoe Bay to Seward (Fig. 2). Although we recognize that the Thornthwaite and Mather (1957) method is perhaps not the most robust technique for estimating potential evapotranspiration in northern latitudes, these results illustrate how interior Alaska has a net negative moisture balance. However, as Guthrie (1990) points out, the presence of an insulating forest litter layer and associated organic-rich soil $\mathrm{O}$ horizon under boreal forest reduces growing season moisture loss from soils. Therefore, the presence of a boreal forest cover, with its litter layer and surface soil horizons, may actually create a positive feedback for forest growth by reducing soil moisture loss. In addition, much of interior Alaska is within the zone of discontinuous permafrost (Péwé, 1975a). As a consequence, where the permafrost table is near the surface, soils tend to be moist throughout the summer growing season because downward-percolating soil water is impeded.

The dominant vegetation at low elevations in interior Alaska is northern boreal forest. Viereck and Little (1972) and Van Cleve et al. (1983) summarize the dominant trees and shrubs on two landscape positions within this biome. On well-drained upland sites, the forest is characterized by white spruce (Picea glauca), paper birch (Betula papyrifera), and aspen (Populus tremuloides). The understory consists of mosses and low shrubs 

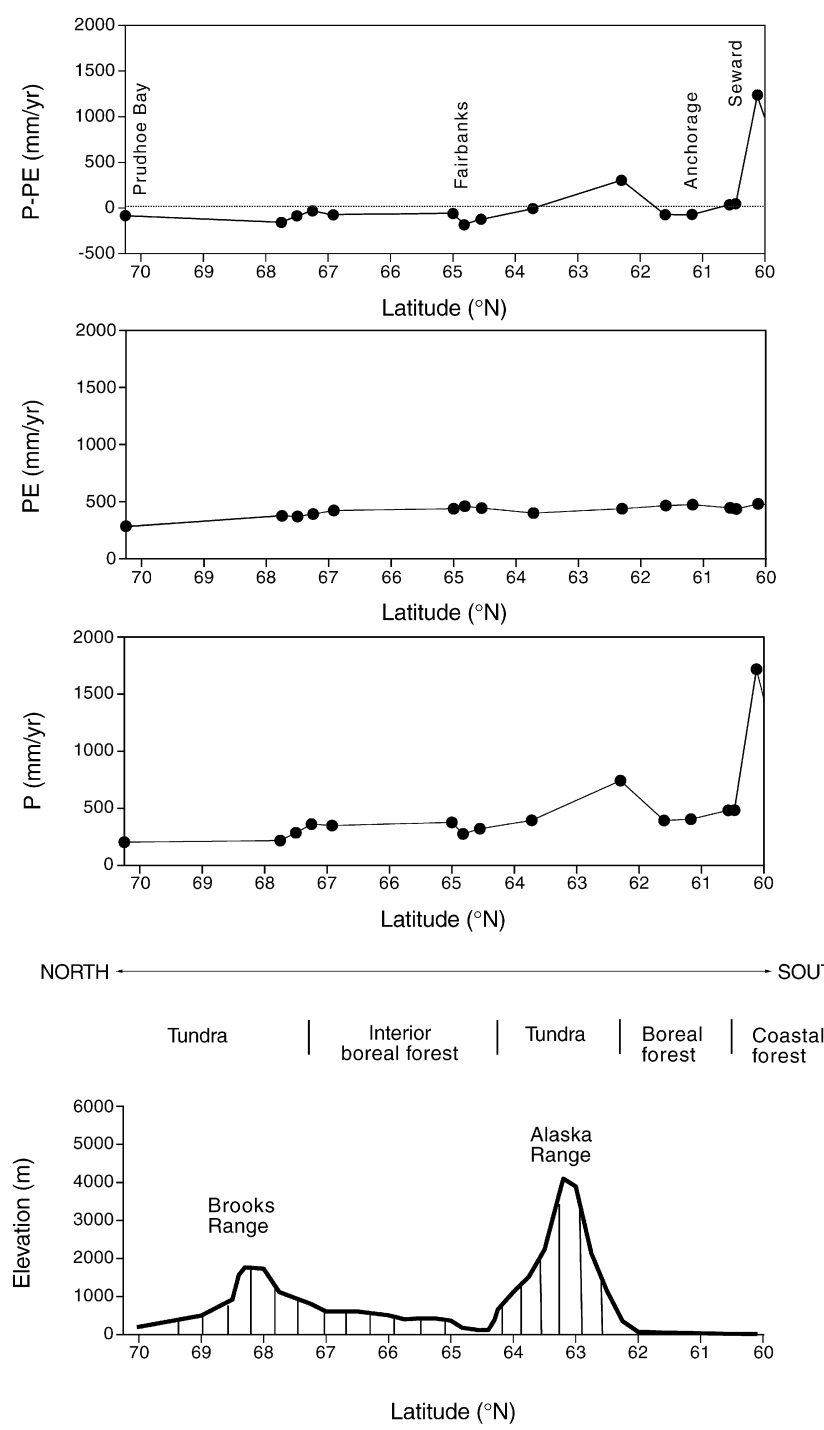

Fig. 2. North-south topographic profile from Prudhoe Bay to Seward, vegetation zones, and plots of mean annual precipitation $(\mathrm{P})$, potential evapotranspiration (PE), and values of P-PE along this transect. Climate data are mostly 1961-1990 means, except where only shorter records are available; PE computed by the authors using the Thornthwaite and Mather (1957) method.

such as currants (Ribes), Labrador tea (Ledum groenlandicum), and blueberry (Vaccinium uliginosum) in moist areas, grasses in dry areas, and willow (Salix), alder (Alnus) and resin birch (Betula glandulosa) in open forests near treeline. Poorly drained lowland sites, particularly those underlain by shallow permafrost, are dominated by black spruce (Picea mariana). Larch (Larix laricina) is found on this landscape position in much of interior Alaska, but has a much more limited distribution than Picea. On poorly drained sites, willow, Labrador tea, shrub birch, blueberry, sedge, and mosses are found in the understory. Altitudinal treeline in interior Alaska is generally around $900-1000 \mathrm{~m}$ (some north- facing slopes have slightly lower treelines), where boreal forest grades into moist (i.e., shrub) tundra characterized by dwarf birch (Betula nana) and willow (Salix), as well as herbaceous taxa.

The factors responsible for the boreal forest boundaries in North America are complex, and have been summarized by Larsen (1989). They include factors recognized by other workers such as length of growing season (Hopkins, 1959) and growing season temperatures (Ritchie, 1987), both of which are influenced by the positions of major air masses (Bryson, 1966). However, Larsen (1989) points out that the northern border of boreal forest is also limited by desiccating winds and low humidity, nutrient-poor, unstable soils, amount of snow cover (as it affects survival of seedlings), and effects of fire. Spruce-dominated boreal forest is rare in areas that have mean July air temperatures lower than about $12^{\circ} \mathrm{C}$ (Fig. 1). In Alaska, the northern climatic boundary to spruce forest is determined altitudinally by the presence of the Brooks Range. It is also important to note that boreal forest in Alaska and Canada contains small enclaves of steppe vegetation where conditions are locally drier, such as on steep, south-facing slopes (Edwards and Armbruster, 1989; Schwarz and Wein, 1997) or where rainshadow effects and katabatic winds combine to produce locally xeric conditions (Laxton et al., 1996).

\section{Stratigraphy and chronology of the Eva Forest Bed}

\subsection{Geochronology of interior Alaska tephras}

Several tephras studied in the Fairbanks area are important in loess stratigraphy (Péwé, 1975a, b; Péwé et al., 1997; Begét, 1988, 1996; Begét et al., 1991; Westgate et al., 1990; Preece et al., 1999), and some have been either directly or indirectly dated by numerical methods. The stratigraphically oldest tephra of interest in the present study is the Sheep Creek tephra, which has been found at a number of localities in interior Alaska and Yukon Territory. The Sheep Creek tephra has not been dated directly, but based on thermoluminescence (TL) ages of bracketing loess is estimated to be about $190 \pm 20 \mathrm{ka}$, although there are some stratigraphic inconsistencies with TL ages at one locality (Berger et al., 1996).

The Old Crow tephra is found above the Sheep Creek tephra at localities where both occur, and has been identified extensively over interior Alaska and Yukon Territory (Westgate et al., 1983, 1985; Begét et al., 1991; Preece et al., 1992, 1999; Begét, 1996). Based on an early attempt at direct dating of the tephra by the fission-track method, Naeser et al. (1982) estimated the Old Crow tephra, collected in Yukon Territory, to be $<120 \mathrm{ka}$. Westgate $(1988,1989)$ used the isothermal-plateau fission-track method for analysis of the Old Crow tephra from the 


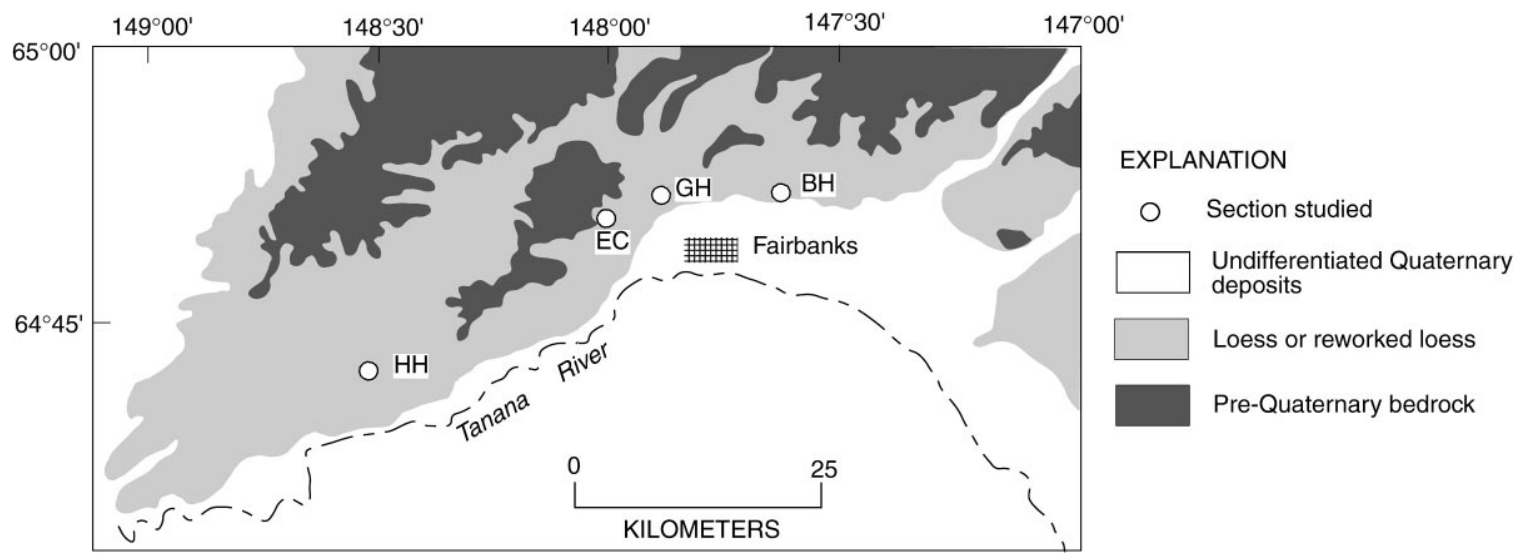

Fig. 3. Map showing the distribution of loess and reworked loess in the Fairbanks area (modified from Péwé et al., 1966), and localities referred to in text. (HH) Halfway House; (EC) Eva Creek; (GH) Gold Hill; (BH) Birch Hill.

Holitna Lowland in southwestern Alaska and the Halfway House section west of Fairbanks (Fig. 3). He reported ages of $150 \pm 20 \mathrm{ka}$ for two analyses from the Holitna Lowland samples, and ages of $120 \pm 20$ and $160 \pm 30 \mathrm{ka}$ for two analyses from the Halfway House samples. These ages are in broad agreement with recent TL age determinations of bracketing loess around the Old Crow tephra reported by Berger et al. $(1994,1996)$. Using the partial bleach method, Berger et al. (1994) reported bracketing TL ages of $140 \pm 30 \mathrm{ka}$ (loess below the Old Crow tephra) and $110 \pm 32 \mathrm{ka}$ (loess above the Old Crow tephra) at the Halfway House locality. At Birch Hill (Fig. 3), where the Old Crow tephra is also found, Berger et al. (1996) reported TL ages of $144 \pm 22 \mathrm{ka}$ (loess below) and $128 \pm 22 \mathrm{ka}$ (loess above). We conclude from these multiple analyses by different techniques, and their associated errors (all given above at $1 \sigma$ uncertainties), that the age of the Old Crow tephra is likely $160-120 \mathrm{ka}$.

The Dome tephra is undated by any direct means. It occurs stratigraphically above the Old Crow tephra at Eva Creek, and is stratigraphically below a paleosol with a likely minimum age of $\sim 39 \mathrm{ka}$ at Gold Hill near Fairbanks (Fig. 3; see Muhs et al., 1997). All that can be said, therefore, is that it is younger than $160-120 \mathrm{ka}$, but older than $\sim 39 \mathrm{ka}$.

\subsection{Stratigraphy of the Eva Forest Bed}

The Eva Forest Bed, exposed in the valley sides of Eva Creek, west of Fairbanks, is a boreal forest litter layer characterized by abundant macrofossils of Picea and Betula, and is interpreted to be of last interglacial age (Péwé, 1975a; Péwé et al., 1997). Critical to the timing and environment of the last interglacial period is the stratigraphy of the Eva Forest Bed, its relations to dated tephras, and the record of fossil vegetation within it.
Péwé et al. (1997) described three tephras, in ascending order the Sheep Creek, Old Crow, and Dome, as occurring in relatively unaltered grey loess (termed the Gold Hill loess) below the Eva Forest Bed. The Eva Forest Bed is described as occurring in the upper part of the Gold Hill loess, without an associated paleosol, and below the Goldstream Formation, an organic-rich silt that is interpreted to represent both direct airfall and colluvially reworked loess. In the interpretation of Péwé et al. (1997), a relatively simple sequence of events is envisioned: the Gold Hill loess is correlated with the penultimate glacial period, an erosional unconformity in the Gold Hill loess and the overlying Eva Forest Bed are correlated with a short last interglacial period, during which permafrost was destroyed, and the Goldstream Formation is correlated with the last-glacial period.

New stratigraphic studies of the Eva Forest Bed at its type locality indicate a complex sequence of events with some important differences from the picture described by Péwé et al. (1997). The top of the exposure we studied is found $\sim 19 \mathrm{~m}$ below the top of the east-facing side of Eva Creek, between the valley head and the Parks Highway, closer to the valley head. A face $\sim 4 \mathrm{~m}$ high and $\sim 16 \mathrm{~m}$ wide was cleared of vegetation and overlying colluvium, gridded, and described in a trench-log fashion (Fig. 4). As best as we can determine, the face studied includes sections "A" and "B" of Fig. 14 of Péwé et al. (1997). The lowermost part of the area exposed shows $\sim 1.5 \mathrm{~m}$ of grey loess, with a weakly developed paleosol. A short distance above this paleosol, a tephra, identified geochemically as the Sheep Creek tephra (Table 1) occurs over a lateral distance of $\sim 5 \mathrm{~m}$. The Sheep Creek tephra is in turn overlain by $1-2 \mathrm{~m}$ of grey loess. In the centralto-southern side of the exposure, a complex, disturbed forest litter layer (soil O horizon) is found, as well as a well-expressed $\mathrm{Bw}$ horizon. The litter layer contains abundant wood and leaf fragments, as well as peaty 

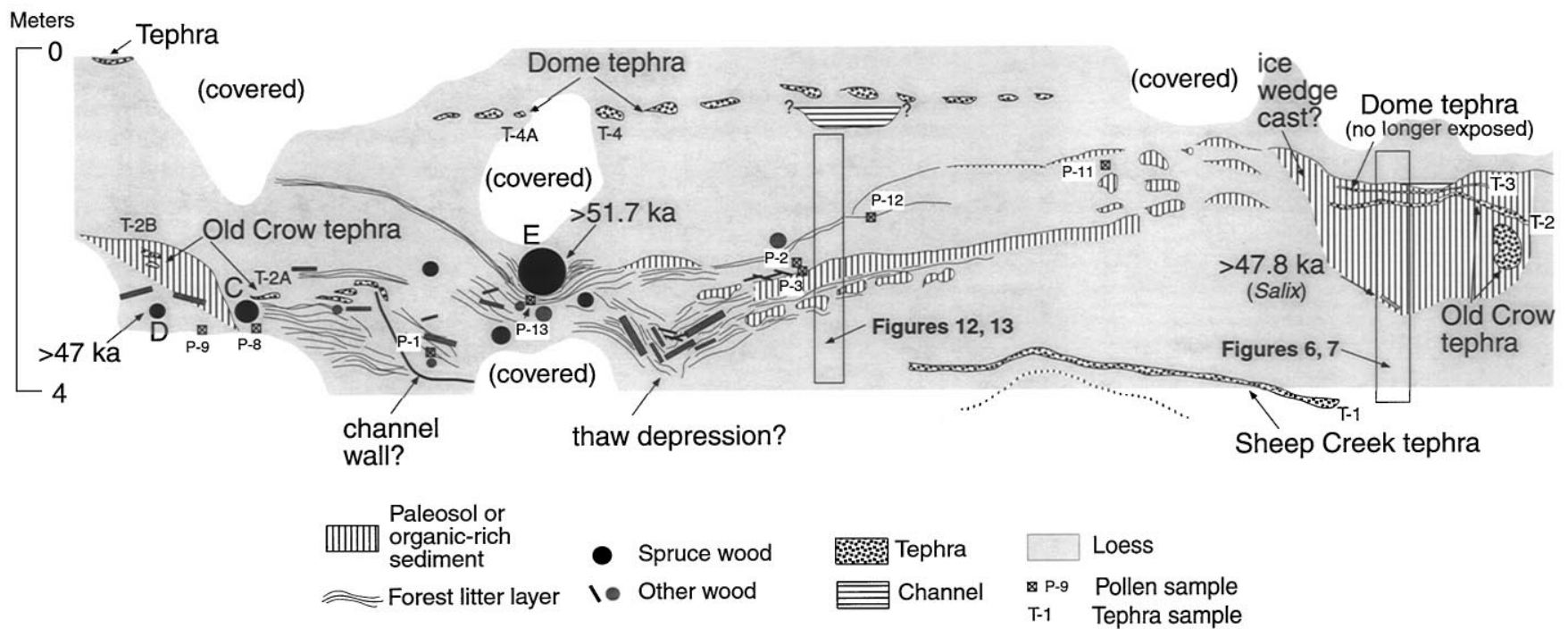

Fig. 4. Stratigraphy of the Eva Forest Bed and units associated with it at the type locality, Eva Creek, near Fairbanks, Alaska.

layers and non-peaty zones of high organic matter content. The layer is not a single discrete horizon, but occurs as splays of variable thickness. All layers, however, have variable degrees of dip toward the left-of-center of the exposure, and wood fragments have highly variable orientations, suggesting that much of the section was disturbed and moved towards a possible thaw depression (Fig. 4). Wood fragments C, D, and E (Fig. 4) were identified as Picea (H. Alden, written communication, 1995; E. Wheeler, written communication, 1997), the largest of which (E) is the same sawed remnant of the spruce log studied by Péwé et al. (1997). This large $\log$ yielded an accelerator mass spectrometric (AMS) radicarbon age of $>51.7 \mathrm{ka}$, consistent with an earlier infinite radiocarbon age (done by conventional beta counting) on a spruce log from the Eva Forest Bed reported by Matthews (1970). Less abundant fragments of Betula papyrifera bark were also found, as well as unidentified pieces of other taxa. The combined evidence of a forest litter layer in the top of grey loess, beyond the limit of radiocarbon dating, and underlain by the Sheep Creek tephra, indicates that this is the Eva Forest Bed at or near its type locality as described by Péwé et al. (1997).

There are several differences between our interpretation of the stratigraphy of the Eva Forest Bed and that of Péwé et al. (1997). The latter workers describe the Old Crow tephra as laterally truncated but occurring stratigraphically below the Eva Forest Bed at the southern end of the exposure (their Fig. 14, section A). However, based on our observations at the south end of the section, the
Old Crow tephra is also found within an organic-rich layer that has, within its lower part (and below the tephra), positively identified spruce wood (sample " $D$ " in Fig. 4), dated by conventional beta counting to $>47 \mathrm{ka}$. Immediately to the north of this organic-rich layer is what appears to be a sloping channel wall, but the Old Crow tephra is found at approximately the same level, or slightly below the level at which it is found in the organic-rich layer. Again, positively identified spruce wood (sample "C") is found below, or at about the same level as the Old Crow tephra. Wood sample $\mathrm{C}$ gave an apparent conventional beta-counted radiocarbon age of $\sim 39 \mathrm{ka}$, which we interpret to be a minimum age. Despite this spurious age, the combined observations at this location lead to the possibility that the Old Crow tephra was deposited at about the same time as the Eva Forest Bed. Another possibility is that the pods of Old Crow tephra we analyzed (sample T2-A and T2-B) were reworked into the forest bed from older deposits that predate the forest bed. An unidentified tephra occurs at the uppermost, southern end of the section exposed in Fig. 4, and could correspond to the laterally truncated Old Crow tephra shown by Péwé et al. (1997) in their Fig. 14 (section A).

Another difference between the present interpretation of the Eva Forest Bed type locality and that of Péwé et al. (1997) is our observation of a morphologically well expressed, though disturbed, paleosol associated with the forest litter layer (Fig. 4). The paleosol has remnant fragments of a black (10YR 2/1, dry Munsell color) or very dark grey (10YR 3/1) O horizon (equivalent to the 
forest litter layers) and possible fragments of a lightcolored $\mathrm{E}$ horizon. It also contains pods of a striking, yellowish-brown (10YR 5/4) Bw horizon that contrast strongly with the underlying light-brownish grey $(2.5 \mathrm{Y}$ 6/2) loess.

A final difference between the stratigraphy of Péwé et al. (1997) and that of the present study is the relation of the Eva Forest Bed to the Dome tephra. The Eva Forest Bed, as we observed it, is overlain by $1-2 \mathrm{~m}$ of grey, largely inorganic loess, and the Dome tephra is found within this loess, clearly stratigraphically above the forest layer (Fig. 4). This contrasts with the stratigraphic relations outlined by Péwé et al. (1997) in their Fig. 14 (section B), which shows the Dome tephra below the forest bed. The new evidence in Fig. 4 indicates that the Dome tephra was deposited after the forest bed was deposited, and in fact, after an episode of loess deposition as well.

The extreme northern end of the face that was described contains deposits that are difficult to correlate with those only a few meters to the south (Fig. 4). The Sheep Creek tephra and the loess overlying it can be traced to the north, but the forest litter layer and associated paleosol with its distinctive Bw horizon are absent here. Instead, a 2-m-thick organic-rich (up to $\sim 13.5 \%$ ) deposit with a wedge-like morphology overlies, or is within the loess. When the site was originally studied by us in 1995 and 1996, the Old Crow and Dome tephras were both found as horizontal bands in the upper part of this wedge, separated by about $20 \mathrm{~cm}$ (shown in Fig. 4). Our tephra samples T2 and T3 are the lower (Old Crow) and upper (Dome) horizontal bands, respectively, that were evident in 1995 and 1996. Later excavation in 1997 removed all evidence of the Dome tephra band, but opened up a large pod of the Old Crow tephra slightly below the horizontal band of Old Crow tephra. Still later excavation in 2000 failed to turn up evidence of the Dome tephra observed in 1995 and 1996, although both the horizontal band and lower pod of Old Crow tephra are still visible. The organic-rich wedge is in turn overlain by loess, some of which appears to be fluvially reworked, as evidenced by channel-like forms filled with small cross-bed sets. Humic acids in the upper part of the wedge sediments gave an AMS radiocarbon age of $\sim 37 \mathrm{ka}$, which we interpret to be a probable minimum age; Salix macrofossils from the lower part of the wedge, $1.45 \mathrm{~m}$ below the previous sample, gave an AMS radiocarbon age of $>47.8 \mathrm{ka}$. Based on field observations made in 2000 with S. Elias, T. Hamilton, E.A. Bettis, $\mathrm{N}$. Bigelow, and S. Preece, we suspect that the organicrich deposits may be an ice wedge cast. If so, its initial formation may predate the deposition of both the Old Crow and Dome tephras (since they are found in its upper part). On the other hand, the vertical distance we observed $(\sim 20 \mathrm{~cm})$ between the Old Crow and Dome tephras differs from that $(>1.0 \mathrm{~m})$ reported by Péwé et al. (1997) for a nearby section (section B, in their Fig. 14) by so much that we also suspect that the Dome tephra may not have been in place when we observed it in 1995 and 1996. Thus, the sediments in the suspected ice wedge cast may predate the Eva Forest Bed, but this is not a certainty.

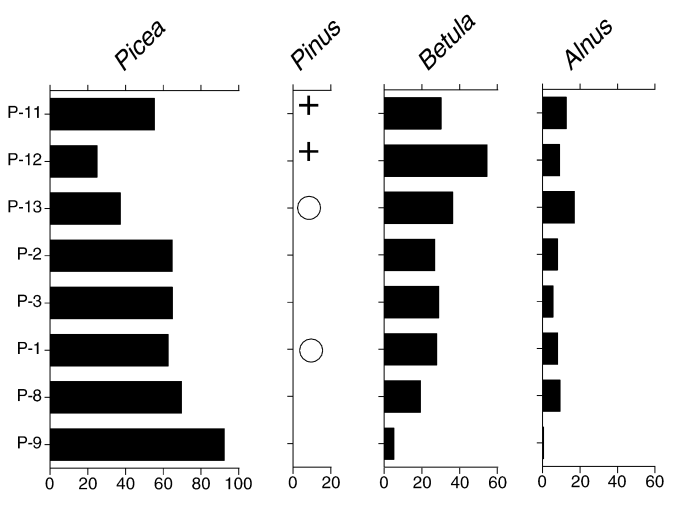

PERCENT OF POLLEN SUM

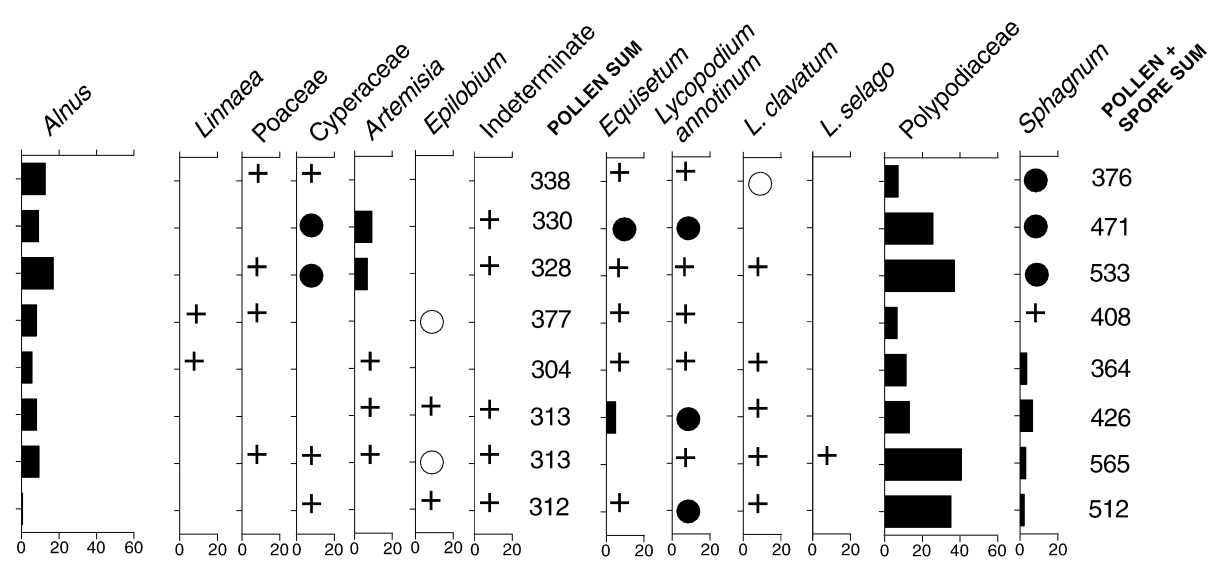

PERCENT OF POLLEN AND SPORE SUM

$=1-2 \%$

$+<1 \%$

Trace amount

Fig. 5. Pollen percentage diagram from the Eva Forest Bed at the type locality. Location of samples shown in Fig. 4. 


\section{Vegetation history recorded by the Eva Forest Bed}

\subsection{Interpretation based on pollen data}

Studies of pollen in the Eva Forest Bed are keyed to the hypothesized sequence of events as outlined in the stratigraphic studies above. In the central and southern portions of the section described, all samples from the forest bed (P-1, 2, 3; P-8, 9; and P-11, 12, 13) contain substantial amounts of Picea pollen, along with lower percentages of pollen of Betula and Alnus (Fig. 5). Pollen of Salix and Ericales are rather poorly represented in most of the samples (and therefore are too low to appear on Fig. 5), as are herbaceous plants such as Poaceae, Cyperaceae, Asteraceae (Artemisia and Tubuliflorae types), and Epilobium. Polypodiaceae spores (monolete fern spores) are unusually abundant in many of the samples, for a site within dry interior Alaska, as compared with Holocene pollen diagrams from boreal forest sites (e.g., Ager, 1975; Hamilton et al., 1983; Anderson et al., 1994; Hu et al., 1993). Other spore types encountered in these samples include Equisetum, Lycopodium annotinum, L. selago, L. clavatum, and Sphagnum moss types. These spore-producing plants are all represented in the modern boreal forests of interior Alaska (Hultén, 1968).

The very high percentages of Picea pollen and Polypodiaceae spores in most of the forest bed samples may in part be a result of differential preservation. The thick walls of Picea pollen and Polypodiaceae spores make these types less vulnerable to oxidation and fungal attack than the thinner-walled pollen types present such as
Betula, Alnus, and Salix. Many of these thinner-walled pollen grains showed evidence of damage by decomposition. Nevertheless, the samples contain sufficient amounts of the thinner-walled taxa to permit reconstruction of the main elements of the Eva Forest Bed flora. The pollen flora is strikingly similar to that of the present-day northern boreal forest of interior Alaska, and is consistent with the macrofossil specimens of Picea and Betula collected in the present study, as well as macrofossil specimens of these same taxa reported by Péwé et al. (1997). The findings reported here suggest that the previously reported pollen, insect, and small mammal evidence found in apparent association with wood of the Eva Forest Bed (Guthrie, 1968; Matthews, 1970) must have been younger, reworked deposits that incorporated wood from the Eva Forest Bed.

Different biota and climate are represented by pollen from the organic-rich wedge sediments and overlying loess from the north side of the section (Figs. 4, 6-9). Three samples within the wedge yielded sufficient pollen grains for counting, as did four samples in the overlying grey loess (or reworked loess). There is a striking difference in the composition of pollen in the wedge compared to the overlying loess (Figs. 8, 9). In the wedge sediments, there is a sedge-dominated tundra assemblage with willows. Willow is also present as a macrofossil in the lower part of the wedge, and gave an AMS radiocarbon age of $>47.8 \mathrm{ka}$, as discussed earlier (Fig. 4). This vegetation assemblage represents a substantially cooler climate than what existed during the interval represented by the Eva Forest Bed.
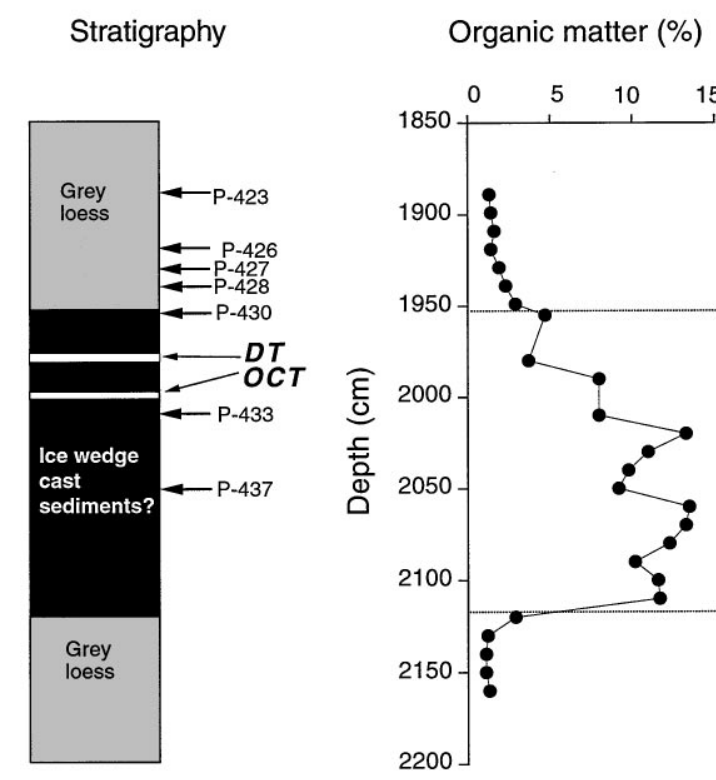

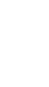

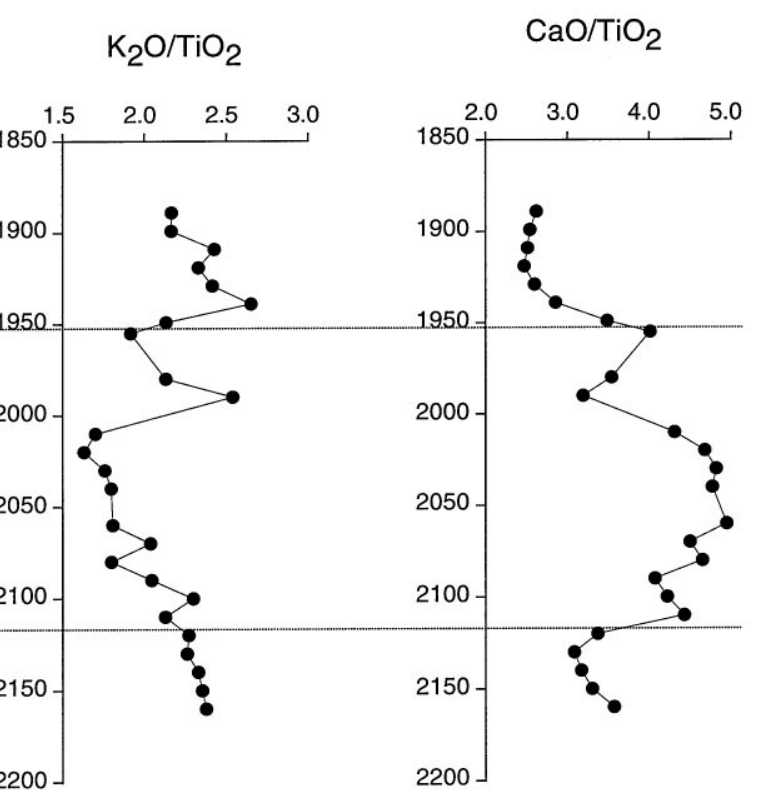

Fig. 6. Detail of the organic-rich sediments in a possible ice wedge cast at the north end of the Eva Forest Bed type locality (location of section shown in Fig. 4), and depth functions of organic matter content, $\mathrm{K}_{2} \mathrm{O} / \mathrm{TiO}_{2}$ values, and $\mathrm{CaO} / \mathrm{TiO}_{2}$ values. Samples with a "P" prefix are pollen samples shown in Fig. 8; (DT) Dome tephra (no longer exposed), (OCT) Old Crow tephra. 
Stratigraphy

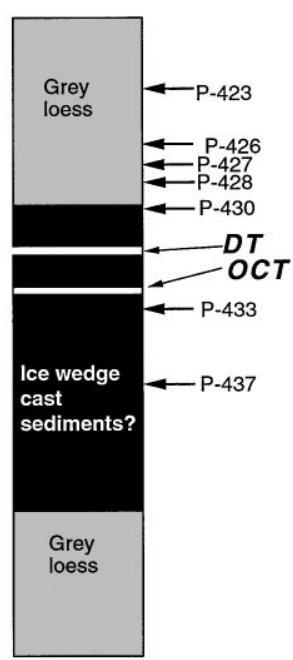

Organic matter (\%)

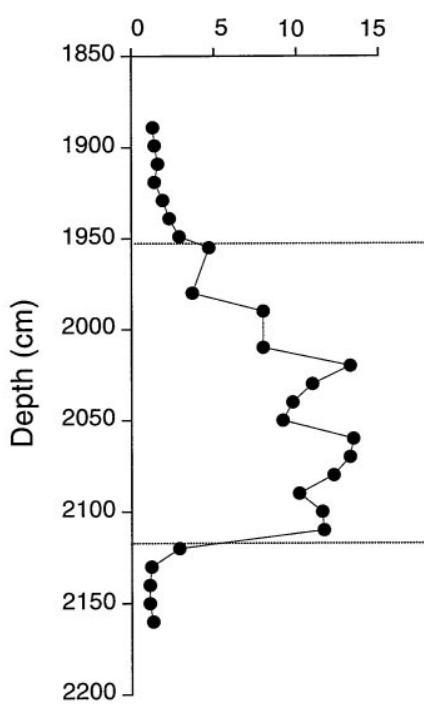

$\mathrm{SiO}_{2} / \mathrm{TiO}_{2}$

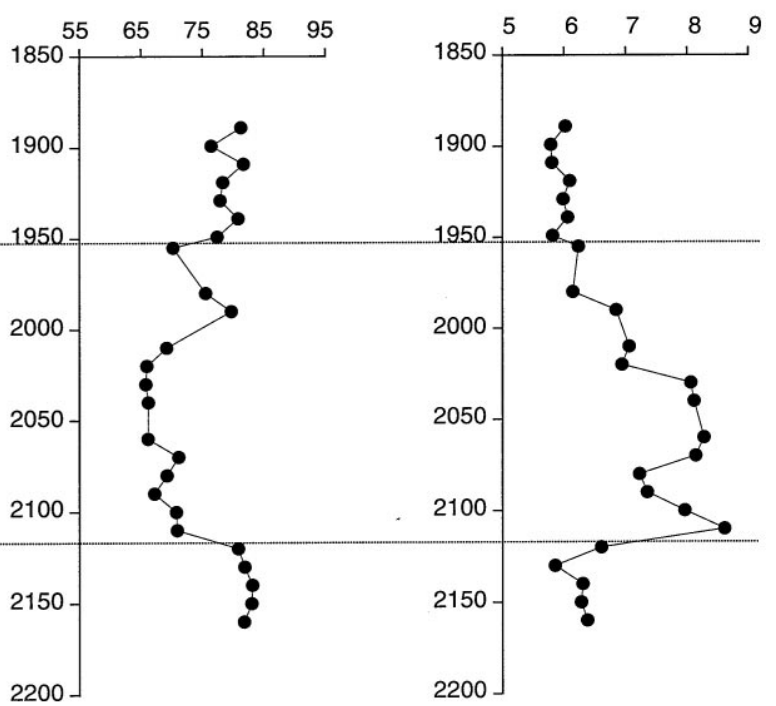

Fig. 7. Detail of the organic-rich sediments in a possible ice wedge cast at the north end of the Eva Forest Bed type locality (location of section shown in Fig. 4), and depth functions of organic matter content, $\mathrm{SiO}_{2} / \mathrm{TiO}_{2}$ values, and $\mathrm{Fe}_{2} \mathrm{O}_{3} / \mathrm{TiO}_{2}$ values. Samples with a "P" prefix are pollen samples shown in Fig. 8; (DT) Dome tephra (no longer exposed), (OCT) Old Crow tephra.

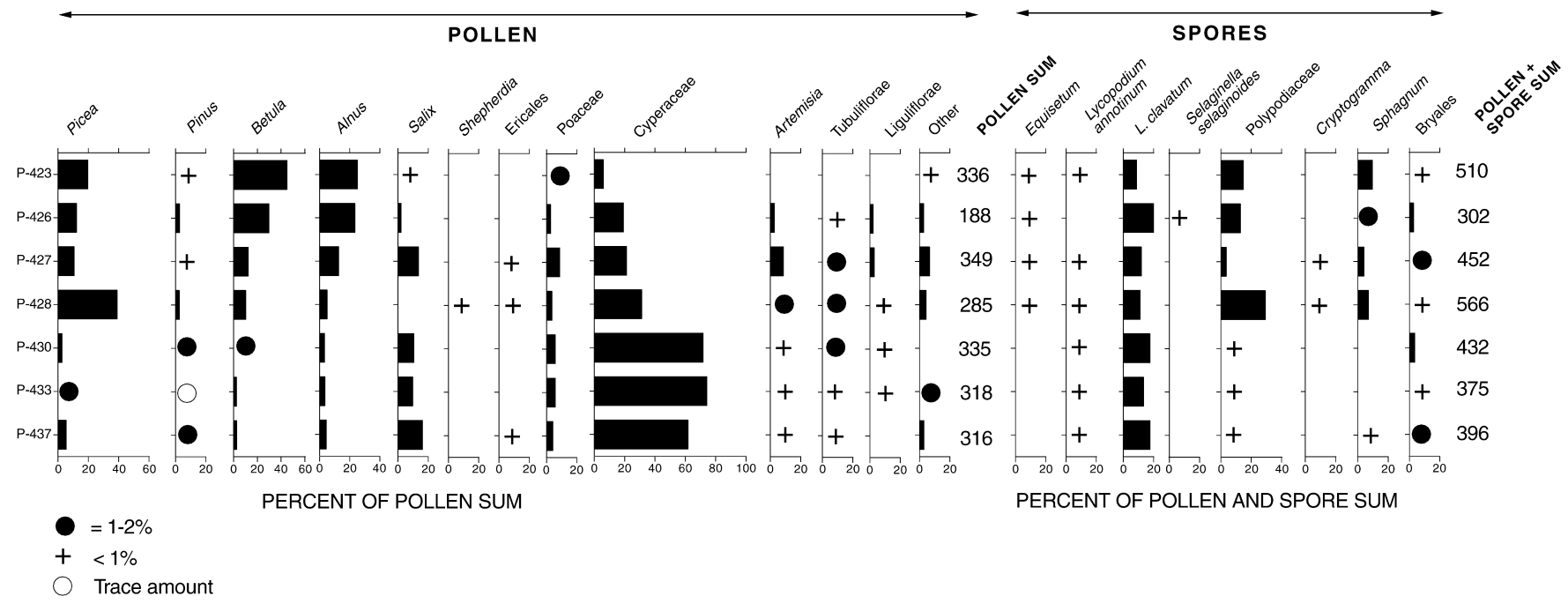

Fig. 8. Pollen percentage diagram from possible ice wedge cast sediment and overlying grey loess at the north end of the exposure of the Eva Forest Bed type locality. Section sampled shown in Fig. 4; pollen samples shown in Figs. 6 and 7.

Above the wedge sediments, the four samples in loess and reworked loess show progressive increases in pollen percentages of Picea, Betula, and Alnus. Such a trend can be interpreted as a migration of boreal forest into the Fairbanks area following the cold interval represented by the sedge-grass-herb tundra samples in the wedge. However, the abundance of Picea pollen is substantially lower than the sample found in the Eva forest Bed. This suggests that the vegetation in the Eva Creek area during this interval may have been open forest-tundra, or perhaps upland tundra with some lowland gallery forests. A corollary intepretation is that the climate was not as warm as the time when the Eva Forest Bed was deposited. However, given the stratigraphic complexity of the wedge sediments and overlying sediments, we are uncertain as to when these events occurred. If the wedge sediments truly predate the Old Crow tephra, which seems the most likely possibility, then the 


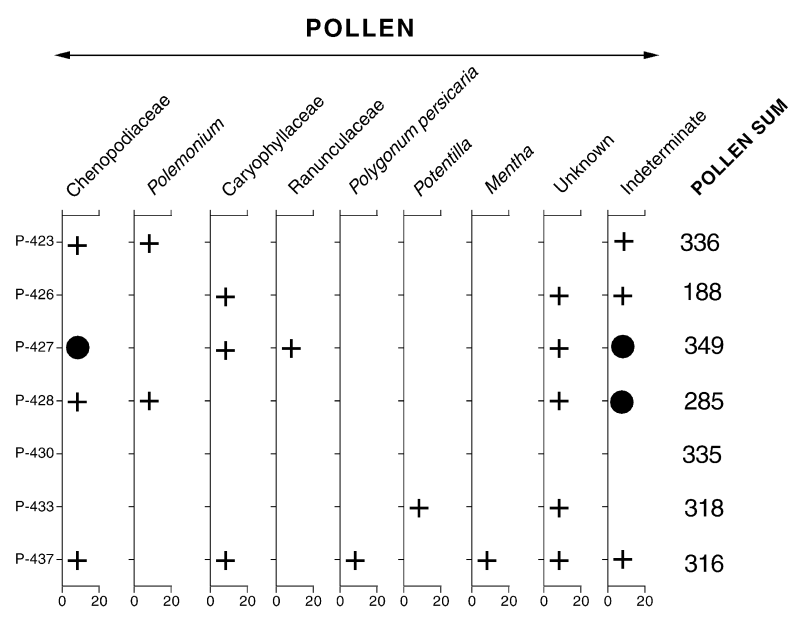

PERCENT OF POLLEN SUM

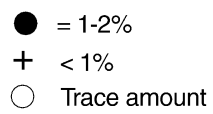

Fig. 9. Pollen percentage diagram for minor taxa shown as "other" in Fig. 8.

sedge-grass-herb tundra pollen assemblage may represent the cold interval preceding the last interglacial period.

\subsection{Interpretation based on soils data}

Buried soils can be identified in section by the presence of key soil horizons, by the relative abundance of organic matter, and by chemical properties that reflect dominant soil-forming processes. Soils usually have high organic matter values in their upper horizons and abundances diminish rapidly with depth (Jenny, 1980), and modern tundra and boreal forest soils in Alaska show this characteristic depth function very clearly (Muhs et al., 2000), although there is a range of organic matter contents in O horizons that spans an order of magnitude (Fig. 10). In addition, boreal forest soils typically show enrichments of key plant nutrients, such as N, P, Ca and $\mathrm{K}$, in their upper horizons due to recycling through plant litter deposition (Van Cleve et al., 1983, 1991, 1993; Muhs et al., 2000). At greater depths, below the O horizon, these elements have abundances that are monotonic with depth, or show evidence of leaching by acidic percolating waters. Modern boreal forest soils in the Fairbanks area also show these typical depth functions: $\mathrm{K}_{2} \mathrm{O}$ and $\mathrm{CaO}$ (normalized to immobile $\mathrm{TiO}_{2}$ ) both show enrichments in $\mathrm{O}$ horizons and either slight leaching or monotonic trends with depth below the O horizon (Fig. 10).

Soil morphological and chemical properties are strongly linked to the soil-forming factors of climate and vegetation, and therefore these properties in paleosols can be useful in inferring past climate and vegetation. Under forest vegetation in many environments, soils develop leached $\mathrm{E}$ (formerly called $\mathrm{A} 2$ ) horizons below the A or O horizon, and over time usually develop subsurface horizons characterized by distinctive structure or color (Bw horizons), clay accumulation (Bt horizons), or accumulation of Fe-oxyhydroxides (Bs horizons). In soils developing under environments characterized by leaching, such as boreal forest, primary minerals, particularly aluminosilicates, experience chemical weathering and lose $\mathrm{SiO}_{2}$ in surface $(\mathrm{O}$ and $\mathrm{A})$ horizons. The development of $\mathrm{Bw}$ or Bs horizons is marked by the accumulation of Fe-oxyhydroxides, resulting in an increase in $\mathrm{Fe}_{2} \mathrm{O}_{3}$ content in subsurface horizons. In warmer and more humid environments, these processes occur at a greater rate. If all other soil-forming factors (composition of soil parent material, age of parent material, vegetation and landscape position) were equal, soils in southern Alaska, which has a longer frost-free period and higher precipitation (Fig. 2), ought to have better-expressed soil profiles and more evidence of chemical weathering than soils in central Alaska.

It is possible to test the hypothesis of greater chemical weathering in southern Alaska compared to central Alaska by examining loess-derived soils of approximately the same age from Fairbanks and Kenai (Fig. 1). In the Fairbanks area, radiocarbon ages indicate that much of the loess that modern soils are developed in is of Holocene age (Hamilton et al., 1983, 1988; Begét, 1990; Péwé et al., 1997; Muhs et al., 1997). On the Kenai Peninsula, loess deposits are commonly underlain by the Lethe tephra (16-12 ka) or contain it in their lower parts, and often have the Crooked Creek or Funny River tephras (8-6 ka) in their middle parts (Reger et al., 1996); thus, the loess soils near Kenai have probably developed in Holocene time as well. Fairbanks area soils in loess have $\mathrm{O} / \mathrm{E} / \mathrm{Bw} / \mathrm{C}$ or only $\mathrm{O} / \mathrm{E} / \mathrm{C}$ profiles that are classified as Inceptisols (Typic Cryochrepts), whereas loess soils in the Kenai area have $\mathrm{O} / \mathrm{E} / \mathrm{Bw} / \mathrm{BC} / \mathrm{C}$ or $\mathrm{O} / \mathrm{E} / \mathrm{Bs} / \mathrm{BC} / \mathrm{C}$ profiles that are classified as Spodosols (Typic Cryorthods) (Fig. 11). Chemical properties are consistent with soil morphology, and indicate greater chemical weathering in Kenai Spodosols compared to Fairbanks Inceptisols. Fairbanks area soils show little or no depletion of $\mathrm{SiO}_{2}$ relative to immobile $\mathrm{TiO}_{2}$, in their $\mathrm{O}$ horizons compared to Kenai soils (Fig. 11). In addition, the morphologically well-expressed $\mathrm{Bw}$ or Bs horizons of Kenai Spodosols show distinct enrichments of $\mathrm{Fe}_{2} \mathrm{O}_{3}$ relative to immobile $\mathrm{TiO}_{2}$, whereas Fairbanks soils show little or no evidence of $\mathrm{Fe}_{2} \mathrm{O}_{3}$ enrichment. We conclude that $\mathrm{SiO}_{2} / \mathrm{TiO}_{2}$ and $\mathrm{Fe}_{2} \mathrm{O}_{3} / \mathrm{TiO}_{2}$ values are good indicators of the degree of chemical weathering in loess-derived soils in Alaska.

Soil morphological and chemical data support the vegetation and climate inferences for the last interglacialcomplex based on pollen data. The soil under the Eva 
Soil horizons

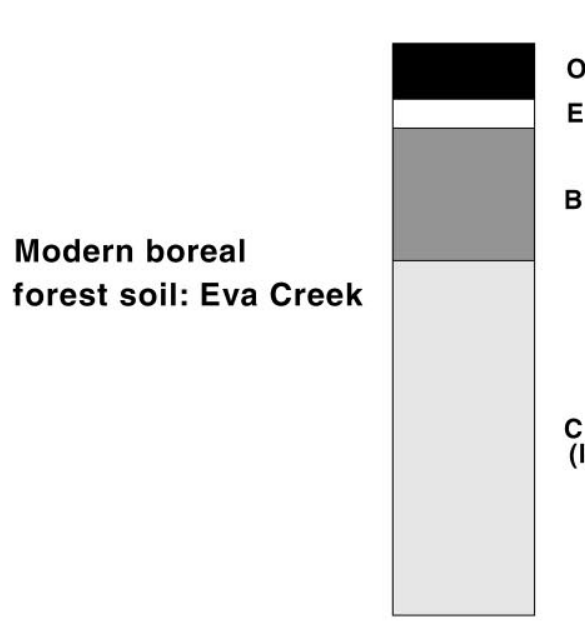

Soil horizons

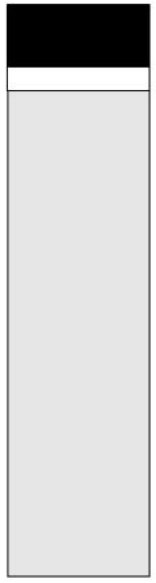

Organic matter (\%)

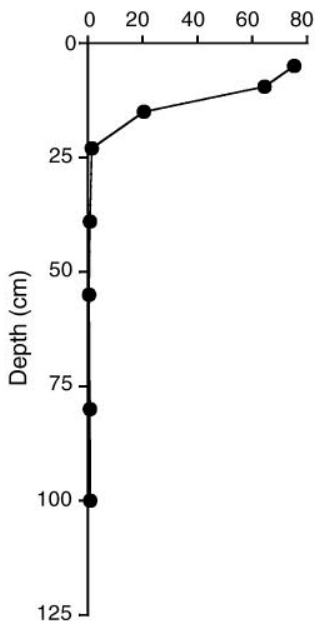

Organic matter (\%)

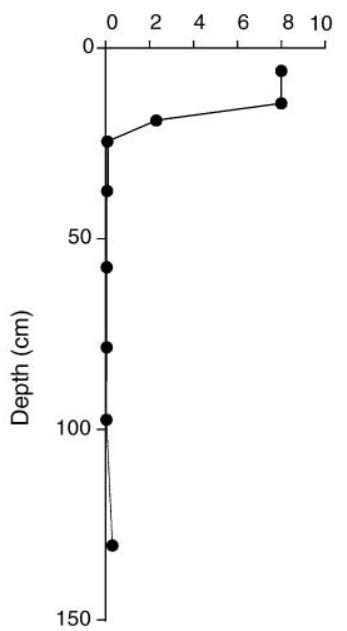

$\mathrm{K}_{2} \mathrm{O} / \mathrm{TiO}_{2}$

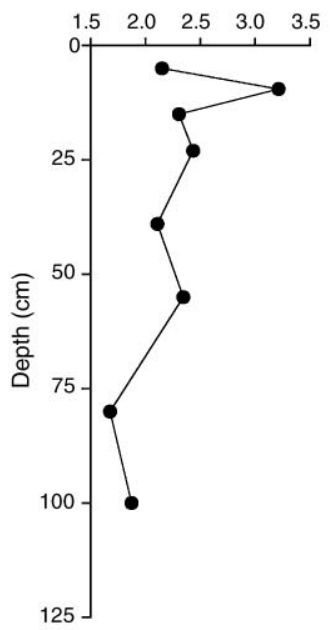

$\mathrm{K}_{2} \mathrm{O} / \mathrm{TiO}_{2}$

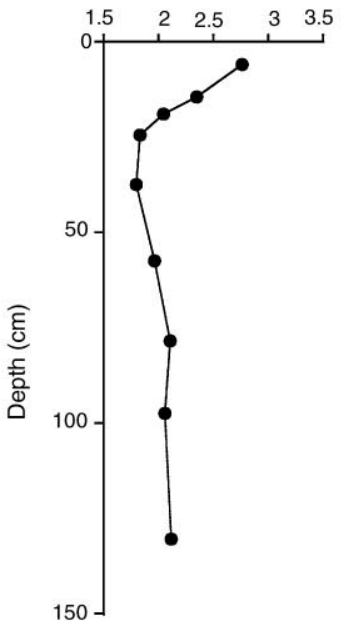

$\mathrm{CaO} / \mathrm{TiO}_{2}$

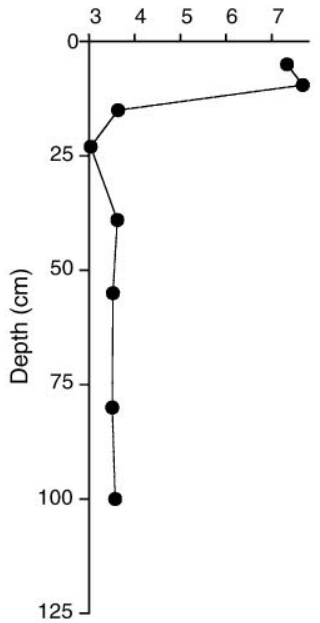

$\mathrm{CaO} / \mathrm{TiO}_{2}$

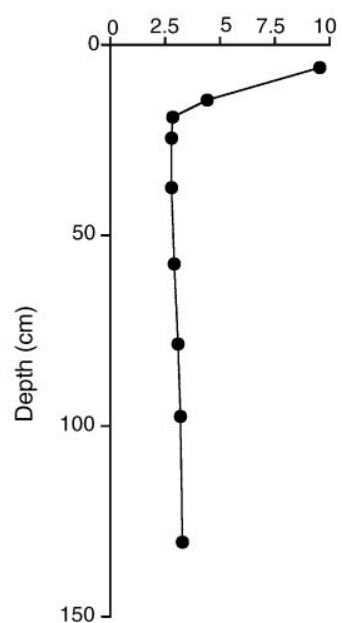

Fig. 10. Soil horizons and depth functions of organic matter content, $\mathrm{K}_{2} \mathrm{O} / \mathrm{TiO}_{2}$ values, and $\mathrm{CaO} / \mathrm{TiO}_{2}$ values in modern boreal forest soils developed in loess at Eva Creek (upper graphs) and Gold Hill (lower graphs); locations shown in Fig. 3.

Forest Bed, although clearly disturbed by cryoturbation, thawing, and slumping, has easily distinguished $\mathrm{O}$ and Bw horizons that resemble those found under boreal forest in Alaska today (Fig. 12). It may also have an E horizon, a leached zone that usually does not form under tundra vegetation, but is common under boreal forest in Alaska (Rieger et al., 1979; Muhs et al., 2000). Organic matter shows highest values in the O horizon, and diminishes rapidly with depth, and both $\mathrm{K}_{2} \mathrm{O}$ and $\mathrm{CaO}$ (normalized to immobile $\mathrm{TiO}_{2}$ ) show relative enrichments in the $\mathrm{O}$ horizon (Fig. 12). These same elements also show depletions in the $\mathrm{Bw}$ horizon relative to the $\mathrm{O}$ horizon above and the unaltered $\mathrm{C}$ horizon (loess) below, indicating some chemical weathering. In addition, $\mathrm{SiO}_{2} / \mathrm{TiO}_{2}$ values are relatively low in the $\mathrm{O}$ horizon and $\mathrm{Fe}_{2} \mathrm{O}_{3} / \mathrm{TiO}_{2}$ values are very high in all horizons, but particularly the Bw horizon (Fig. 13). Overall, the soil under the Eva Forest Bed shows more evidence of chemical weathering than is found in modern Fairbanks area Inceptisols, and is similar to the degree of chemical weathering in Kenai area Spodosols (cf. Fig. 11). These observations indicate the Eva Forest Bed paleosol may have developed under higher-than-present precipitation during the last interglacial, which is consistent with the higher-than-modern abundance of monolete spores observed in the Eva Forest Bed itself.

An alternative explanation is that the Eva Forest Bed paleosol experienced a longer period of pedogenesis under boreal forest than have modern Fairbanks area soils. At Eva Creek, the modern soil formed in loess that is less than about $8900 \mathrm{yr}$ old (Muhs et al., 1997). The peak of the last interglacial period (equivalent to deep-sea 

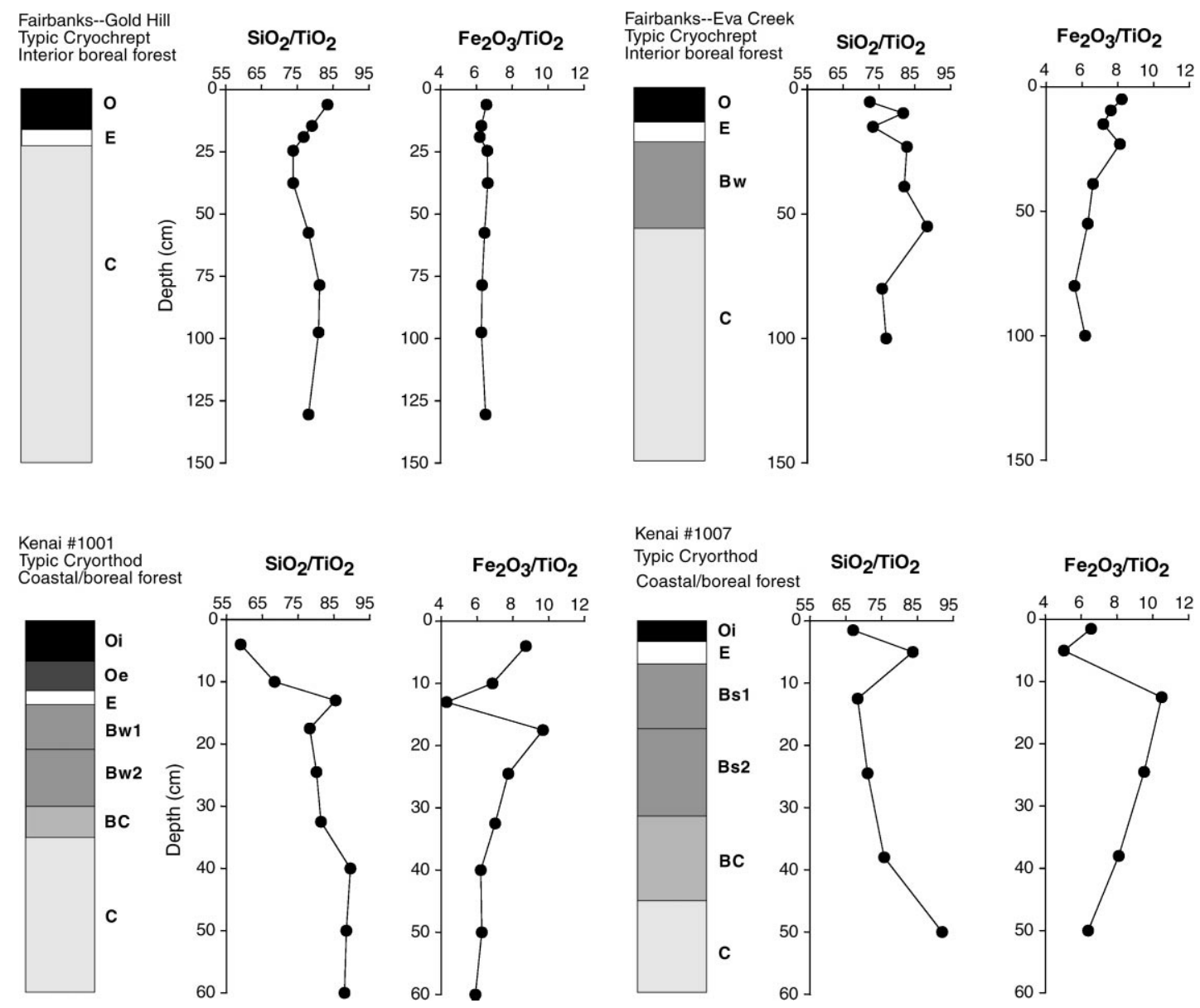

Fig. 11. Depth functions of $\mathrm{SiO}_{2} / \mathrm{TiO}_{2}$ and $\mathrm{Fe}_{2} \mathrm{O}_{3} / \mathrm{TiO}_{2}$ values in modern boreal forest soils at Eva Creek and Gold Hill (locations shown in Fig. 3) and modern coastal/boreal forest soils developed in loess near Kenai, Alaska Kenai area shown in Fig. 1; precise soil localities given in Muhs et al. (2000).

oxygen isotope substage 5e), on the other hand, is interpreted to be as short as a few thousand years, based on the deep-sea oxygen isotope record (Martinson et al., 1987), to as long as $15-20 \mathrm{kyr}$, based on marine terrace and reef studies (Szabo et al., 1994; Muhs and Szabo, 1994; Muhs et al., 1994), the Devils Hole calcite record (Winograd et al., 1992), and ice core records (Lorius et al., 1985; Jouzel et al., 1993). Hence, the greater degree of chemical weathering shown in the paleosol under the Eva Forest Bed compared to modern Fairbanks-area soils could very well be due to a longer period of pedogenesis. At present, there is no method by which we can favor one explanation over the other for the genesis of the Eva Forest Bed paleosol.

The organic-rich ice-wedge cast sediments at the north end of the exposure, with their tundra-dominated pollen spectra, show characteristics somewhat different from the soil under the Eva Forest Bed (Figs. 6, 7). Organic matter content is not as high as in the $\mathrm{O}$ horizons of modern boreal forest soils and, although higher than in the host loess, shows an irregular shift in abundance with depth.
Chemical data for wedge sediments show conflicting trends. $\mathrm{CaO}$ shows considerable enrichment, indicating a lack of leaching (Fig. 6). Soils that formed during the last glacial maximum on the Seward Peninsula under tundra vegetation also show no evidence of leaching (Höfle and Ping, 1996), consistent with tundra-dominated pollen records that indicate a cold, dry climate at that time (Ager, 1982). However, the $\mathrm{K}_{2} \mathrm{O} / \mathrm{TiO}_{2}$ and $\mathrm{SiO}_{2} / \mathrm{TiO}_{2}$ depth functions show evidence of $\mathrm{K}_{2} \mathrm{O}$ and $\mathrm{SiO}_{2}$ loss relative to the host loess, and there is a significant enrichment of $\mathrm{Fe}_{2} \mathrm{O}_{3}$ relative to $\mathrm{TiO}_{2}$ (Figs. 6, 7). We conclude that the ice wedge cast sediments are probably derived from eroded surface soil horizons.

\subsection{Correlation of last interglacial records at Eva Creek}

We propose that the pollen and soil record at Eva Creek reflects the changing climatic conditions of the last interglacial complex. Based on the previously reported combined fission-track and TL age estimates discussed above and the stratigraphic evidence presented here, we correlate the spruce-bearing portions of the Eva Forest 


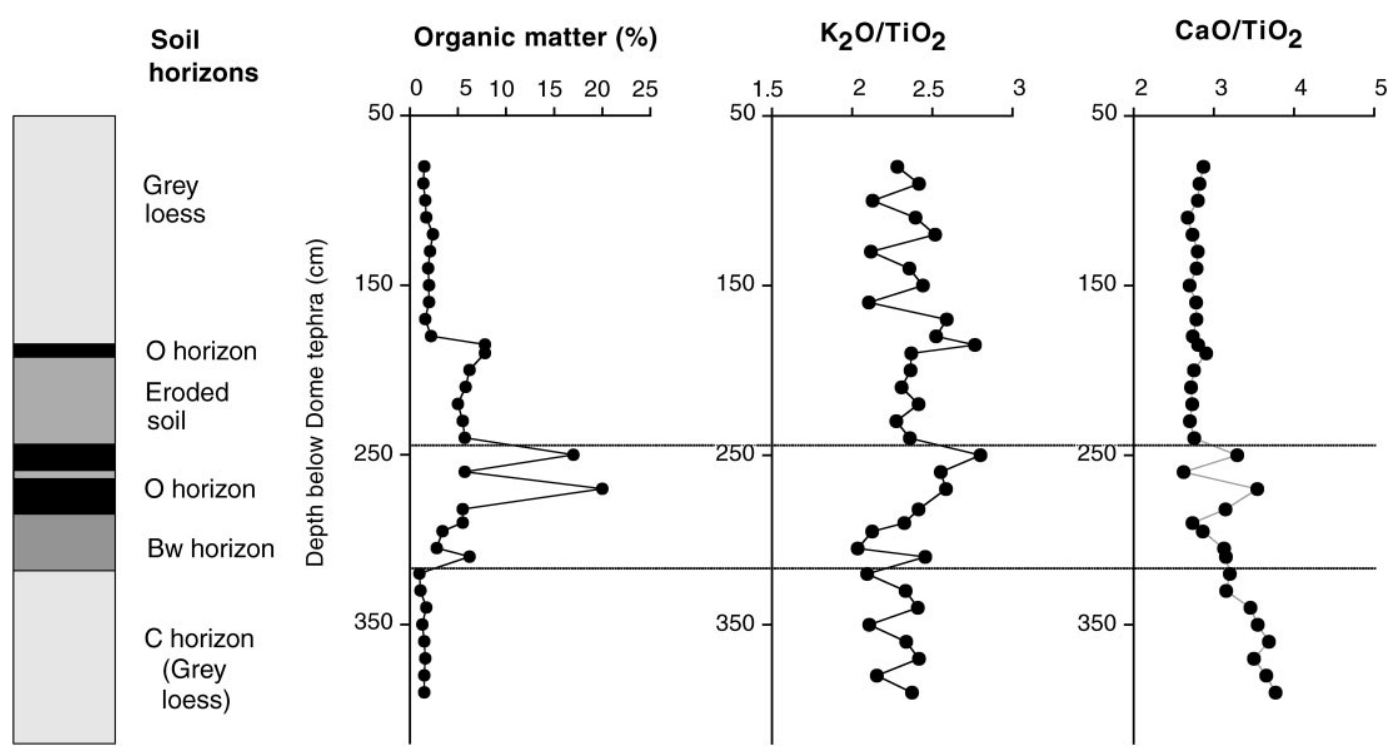

Fig. 12. Detail of the paleosol associated with the Eva Forest bed (location of section shown in Fig. 4), and depth functions of organic matter content, $\mathrm{K}_{2} \mathrm{O} / \mathrm{TiO}_{2}$ values, and $\mathrm{CaO} / \mathrm{TiO}_{2}$ values.

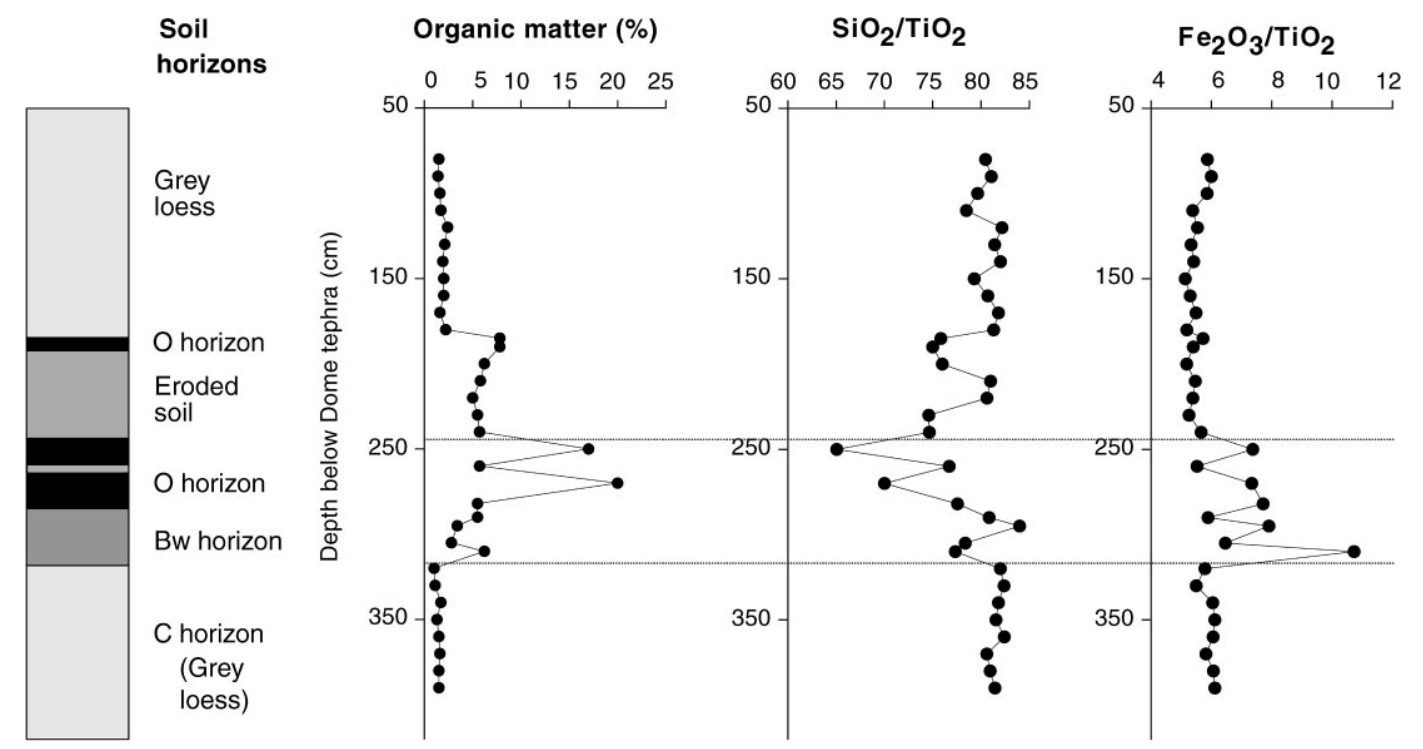

Fig. 13. Detail of the paleosol associated with the Eva Forest bed (location of section shown in Fig. 4), and depth functions of organic matter content, $\mathrm{SiO}_{2} / \mathrm{TiO}_{2}$ values, and $\mathrm{Fe}_{2} \mathrm{O}_{3} / \mathrm{TiO}_{2}$ values.

Bed to the peak of the last interglacial period arond $126 \mathrm{ka}$, when summer insolation near Fairbanks was at its highest values of the past $200 \mathrm{kyr}$ (Fig. 14). The organic-rich ice wedge cast which contains the Old Crow tephra (and originally the Dome tephra) at the northern end of the exposure at Eva Creek (Fig. 4) could predate the Eva Forest Bed, suggesting the peak of the last interglacial period was preceded by a cold, dry period where tundra vegetation dominated. This cold period could correlate with the penultimate glacial period, when insolation was low, as was the case during the last glacial period, when tundra vegetation was also dominant in interior Alaska (Fig. 14).

\section{Paleoclimate of the last interglacial period in Alaska and Yukon}

\subsection{Inferences based on permafrost thawing and soils}

Péwé et al. (1997) report that during the last interglacial interval, climatic warming was substantially 


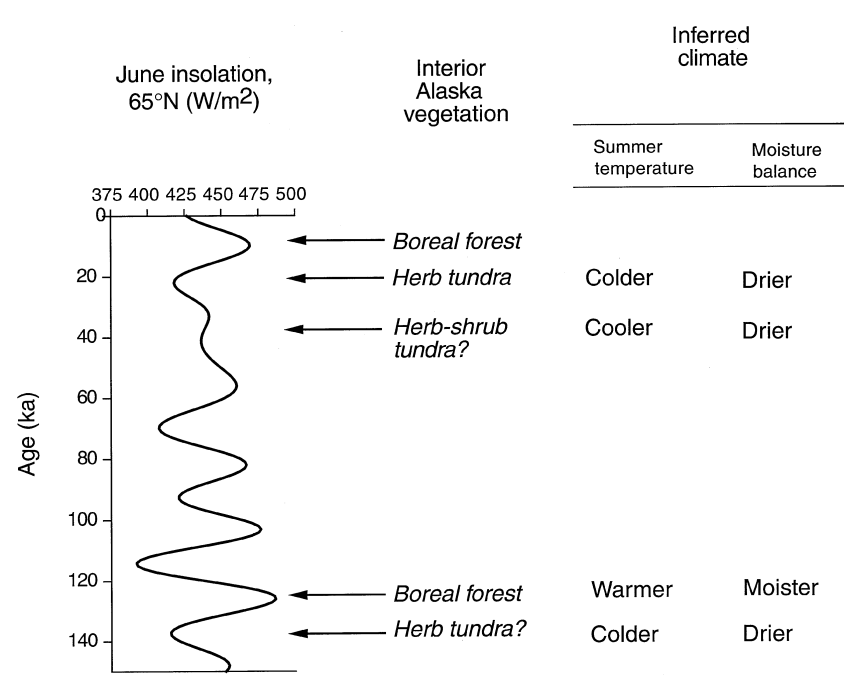

Fig. 14. Summary of vegetation and inferred climate in interior Alaska and comparison with July insolation at the top of the atmosphere at $65^{\circ} \mathrm{N}$ latitude over the period from about 150 to present. Insolation data from Berger and Loutre (1991); pollen data for periods younger than the Last Interglacial period are from Ager $(1975,1983)$, Ager and Brubaker (1985) and Hamilton et al (1988).

greater than during any part of the present Holocene warming. Based on their reports of a distinct erosional unconformity beneath the Eva Forest Bed, as well as evidence of extensive gullying and slump block movements in loess, Péwé et al. (1997) infer that it was sufficiently warm to destroy the permafrost that had existed in interior Alaska during the penultimate glacial period ( $\sim 190 \mathrm{ka}$ to $\sim 140 \mathrm{ka}$, or approximately equivalent to deep-sea oxygen isotope stage 6 of Martinson et al. (1987)). This warming would have preceded the migration of the boreal forest into interior Alaska and the formation of the Eva Forest Bed or there would be no record of the forest. Thus, we infer that Péwé et al.'s (1997) interpretation is that the insolation maximum at $\sim 126 \mathrm{ka}$ at latitude $65^{\circ} \mathrm{N}$ (Berger and Loutre, 1991) would have produced warming that first thawed permafrost and was then followed by development of boreal forest. The insolation maximum at the close of the last-glacial period occurred around $11 \mathrm{ka}$ (Berger and Loutre, 1991), but boreal forest did not arrive into eastern interior Alaska until about 9-8 ka (Ager, 1975, 1983; Ager and Brubaker, 1985). However, permafrost is still present in much of interior Alaska, including all but upland areas of the Fairbanks region.

Péwé (1975a) has admirably summarized the climatology of permafrost in Alaska, and demonstrated that the present boundary between the zone of no permafrost and the zone of discontinuous permafrost in southernmost Alaska coincides closely with the $0^{\circ} \mathrm{C}$ mean annual air temperature isotherm. The present mean annual air tem- perature in Fairbanks and the surrounding area is $-2.8^{\circ} \mathrm{C}$. Thus, in order to thaw permafrost in the Fairbanks area, it would be necessary to raise temperatures at least $3^{\circ} \mathrm{C}$. If the interpretations of permafrost melting by Péwé et al. (1997) are correct, temperatures during at least the first part of the last interglacial period were considerably warmer than present. However, our findings at Eva Creek are not consistent with the order of events as outlined by these workers. Stratigraphic studies reported here show that the Eva Forest Bed itself and its paleosol are deformed, due to the creation of what appears to have been a thaw depression (Fig. 4). If this interpretation is correct, then the forest bed had to exist before the destruction of permafrost, not after.

Many of Péwé et al.'s (1997) interpretations about permafrost melting are based on numerous observations of laterally extensive mining cut exposures that were available during the 1940s and 1950s. Most of these exposures are now largely slumped and revegetated or otherwise unavailable for study. Therefore, although we observed evidence of deformation of the Eva Forest Bed, there are very minimal exposures available near Eva Creek now compared to what Péwé was able to observe over the past several decades.

\subsection{Inferences based on pollen and macrofossil studies}

The presence of spruce macrofossils and spruce-dominated pollen in the Eva Forest Bed indicates that July temperatures in the Fairbanks area were at least $12^{\circ} \mathrm{C}$. Because present July temperatures in Fairbanks are about $16.9^{\circ} \mathrm{C}$, the pollen and macrofossil data do not necessarily imply that last interglacial temperatures were warmer than present. However, the combination of pollen and macrofossil data and Péwé et al.'s (1997) inferences about the timing of permafrost destruction and boreal forest development during the last interglacial present an interesting problem with respect to moisture availability in interior Alaska. In the Fairbanks area today, mean annual precipitation $(\mathrm{P})$ is $276 \mathrm{~mm} / \mathrm{yr}$, and in climatic terms, there is a net moisture deficit, around $-184 \mathrm{~mm}$, based on estimates of potential evapotranspiration (PE) (Fig. 2). As discussed earlier, boreal forest can survive today under this negative moisture balance regime because of the presence of permafrost and thick, insulating soil $\mathrm{O}$ horizons, which reduce downward soil water percolation and upward evaporative soil water loss. If $\mathrm{P}$ were no greater than present during the last interglacial period and permafrost was absent due to warmer summers, it would be difficult to support a boreal forest, and a cool-season steppe would be the likely vegetation. This proposition is supported by a recent study demonstrating that the southern border of boreal forest in western Canada correlates best with P-PE. When P-PE is less than zero, boreal forest is 
replaced by aspen parkland, and when a value of around $-150 \mathrm{~mm}$ is reached, cool steppe replaces aspen parkland (Hogg, 1994). However, evidence that the Eva Forest Bed itself was deformed by the creation of a thaw depression suggests that permafrost was present during at least part of the last interglacial period. Thus, part of the potential negative moisture balance would have been compensated by the presence of permafrost, similar to the environment of interior Alaska today.

In addition, maintenance of northern boreal forest similar to that of the present in interior Alaska could have occurred during the last interglacial, even with warmer summers, with higher-than-present precipitation. This possibility is supported by the relative abundance of Polypodiaceae spores in most of the Eva Forest Bed samples analyzed, as well as the evidence for a high degree of chemical weathering in the paleosol under the forest bed. As discussed above, most Holocene pollen diagrams from sites in interior Alaska show low percentages of fern spores (Ager, 1975; Hamilton et al., 1983; Anderson et al., 1994; Hu et al., 1993). In contrast, Holocene pollen diagrams from sites in south-central
Alaska near the Gulf of Alaska often show relatively high percentages of fern spores compared to interior sites (Heusser, 1960, 1983; Ager, 1983; Peteet, 1986). This difference is most reasonably explained by greater precipitation near coastal areas vs. interior areas (Fig. 2). It is unclear whether the apparent abundance of Polypodiaceae type spores found in the Eva Forest Bed is a regional or local phenomenon, although percentages of Polypodiaceae (monolete) spores in the last interglacial record at Birch Creek, north of Fairbanks, are also generally higher than in most Holocene pollen records currently available from interior Alaska (Edwards and McDowell, 1991). The relative abundance of Polypodiaceae spores in these samples is probably in part an artifact of differential preservation, as discussed above, but since both Picea pollen and Polypodiaceae spore percentages are high in all of the samples, it is likely that both taxa were well represented in the forest flora. We conclude, on the basis of both moisture balance considerations as well as fossil spore and paleosol evidence, that precipitation in central Alaska must have been greater than present during the last interglacial period.

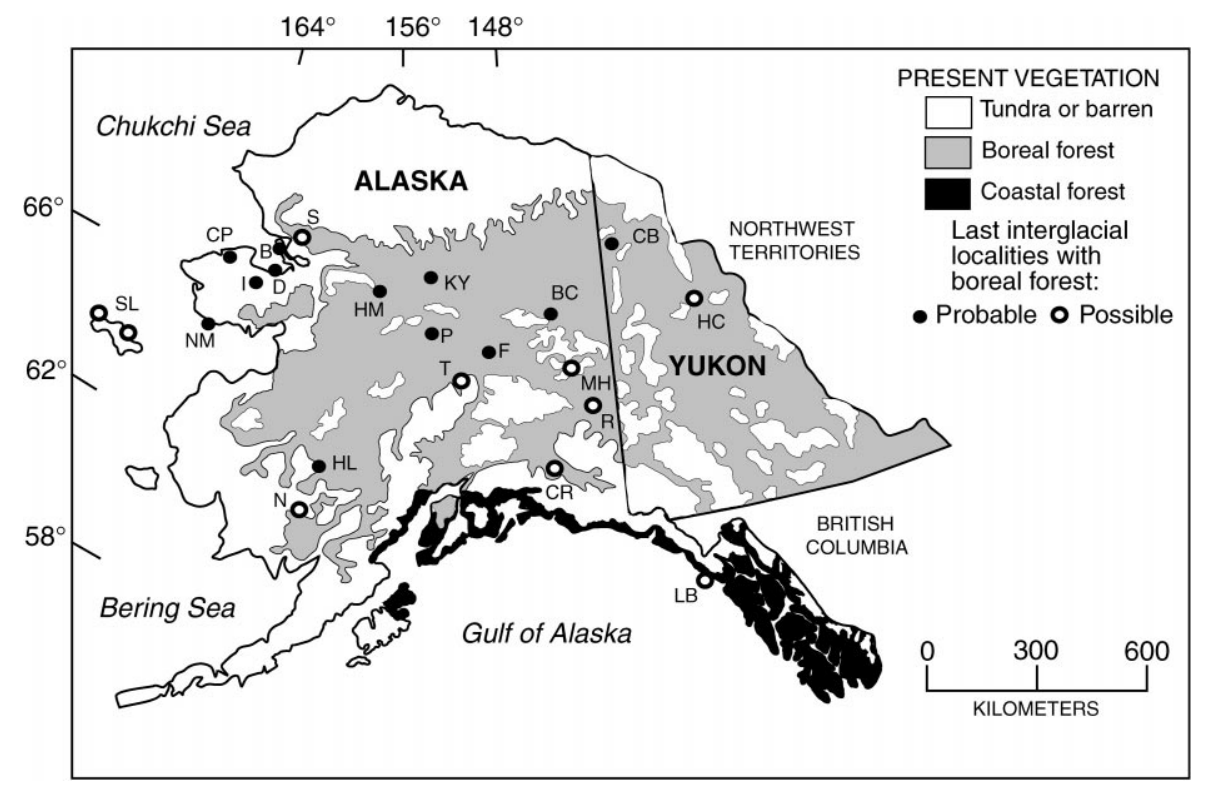

Fig. 15. Map showing the present distribution of vegetation communities in Alaska and Yukon (from Viereck and Little, 1972, as redrawn by Ager and Brubaker, 1985, and National Atlas Information Service and Petawawa National Forestry Institute, 1993), and locations of probable and possible last interglacial sites with boreal forest indicators (either pollen or macrofossils) in Alaska and adjacent Yukon. Localities plotted and sources of data: (SL) St. Lawrence Island (Colinvaux, 1967; Maeda, 1985); (B) Baldwin Peninsula (McCulloch et al., 1965; Hamilton and Brigham-Grette, 1991; Brigham-Grette and Hopkins, 1995); (NM) Nome (Brigham-Grette and Hopkins, 1995); (D) Deering (Brigham-Grette and Hopkins, 1995); (CP) Cowpack River (Brigham-Grette and Hopkins, 1995); (MH) Mount Harper (Weber and Ager, 1984); (R) Riverside Bluff (Fernald, 1965); (N) Nuyakuk (Elias and Short, 1992); (CB) Ch'ijees Bluff(Matthews et al., 1990; Schweger and Matthews, 1991); (HC) Hungry Creek (Schweger and Matthews, 1991); (T) Toklat River (Elias et al., 1996); (LB) Lituya Bay (Mann, 1986); (CR) Copper River Basin (Ager, 1989); (P) Palisades of the Yukon (Begét et al., 1991); (S) Squirrel Lake (P. Anderson in Hamilton and Brigham-Grette, 1991); (KY) Koyukuk River (Hamilton and Brigham-Grette, 1991; Seidenkrantz et al., 1996); HM, Hogatza Mine (Hamilton and Brigham-Grette, 1991); (I) Imuruk Lake (Colinvaux, 1964; Shackleton, 1982); (BC) Birch Creek (Edwards and McDowell, 1991); (HL) Holitna Lowland (Waythomas et al., 1993); (F) Fairbanks (Péwé et al., 1997; this study). 


\subsection{Other last interglacial boreal forest evidence in Alaska and Yukon}

Enough pollen and macrofossil localities have been reported for Alaska and Yukon that it is now possible to sketch a regional picture of the probable extent of boreal forest during the last interglacial period. In compiling a mapped summary of these localities, we consider "probable" last interglacial localities as those where the hypothesized last interglacial deposits have infinite radiocarbon ages and are in close association with either the Old Crow tephra or aminostratigraphically correlated Pelukian (= last interglacial) shoreline deposits. We consider "possible" last interglacial deposits to be those with infinite radiocarbon ages and in a stratigraphic position that permits a last interglacial correlation (i.e., overlain by dated deposits of last-glacial age).

Results of this compilation show a last interglacial boreal forest that was more extensive than the modern one (Fig. 15). Well-studied, spruce-pollen-bearing or spruce-macrofossil-bearing localities associated with the Old Crow tephra are numerous in the interior of Alaska and Yukon Territory, and include sites at Ch'ijees Bluff (Matthews et al., 1990; Schweger and Matthews, 1991), at the Palisades of the Yukon (Begét et al., 1991), along the Koyukuk River (Hamilton and Brigham-Grette, 1991; Seidenkrantz et al., 1996); at Hogatza Mine (Hamilton and Brigham-Grette, 1991), along Birch Creek (Edwards and McDowell, 1991), and in the Holitna Lowland (Waythomas et al., 1993). Localities showing extensions of boreal forest onto what is at present tundra are found on the Seward and Baldwin Peninsulas along the Cowpack River and at Nome, Deering, Kotzebue, and Imuruk Lake (Brigham-Grette and Hopkins, 1995; Colinvaux, 1964; Shackleton, 1982). There may have been a rise of last interglacial treeline to higher altitudes where foresttundra and tundra now exist in interior localities such as the Yukon-Tanana Upland (Weber and Ager, 1984). Spruce-dominated boreal forest probably spread to western St. Lawrence Island, based on high spruce pollen contents in the lower parts of a lake core associated with an infinite radiocarbon age (Maeda, 1985). Spruce is also present, although not as abundant, near the base of another lake core from central St. Lawrence Island, and was interpreted to represent last interglacial deposits (Colinvaux, 1967). Boreal forest expansion to the north of the Brooks Range is not yet documented, but the occasional occurrence of spruce wood in fluvial and shoreline deposits of the Arctic coast (Carter and Ager, 1989; Carter in Brigham-Grette and Hopkins, 1995) suggests that it is likely and should be investigated further.

\subsection{Synthesis and comparison with climate models}

The overall picture that emerges for Alaska and Yukon during the peak warmth of the last interglacial is a region with warmer-than-present summers, an absence of permafrost in the interior, and probably greater precipitation in the interior. The most surprising implication of our study, based primarily on spore data and secondarily on soil data, is the notion of higher precipitation in the interior of Alaska during the last interglacial. This unexpected finding has important implications for climate models of the last interglacial and requires discussion of possible mechanisms.

The present synoptic climatology of Alaska and Canada is summarized by Bryson and Hare (1974) and Hare and Hay (1974). These workers demonstrate, through mapping of mean streamline positions, that during much of the fall, winter, and spring, interior Alaska is dominated by the presence of cold, dry Arctic air masses, and little precipitation occurs. In the late spring, summer, and early fall, moister and warmer air masses from the north Pacific Ocean and Bering Sea dominate interior Alaska, and precipitation, though still not abundant, is much higher than during the winter. More precipitation could be derived from Pacific air were it not for the presence of the Alaska Range, which exerts a rain shadow effect on interior Alaska.

Even with the presence of the Alaska Range, however, greater precipitation in the interior of Alaska could be achieved if more moisture were available from the surrounding oceans through a decrease in the residence time of sea ice. The Arctic Ocean has a permanent sea ice cover, with only a narrow channel that fringes the northern coast of Alaska opening in summer, and the Bering Sea has a significant sea ice cover in winter. BrighamGrette and Hopkins (1995) point out that Pelukian (last interglacial) marine terrace deposits in western and northern Alaska contain extralimital southern mollusks whose presence requires a perennially ice-free Bering Sea and an Arctic Ocean with at least greatly reduced sea ice cover. Recent modeling experiments by Crowley et al. (1994) demonstrate that with removal of Arctic Ocean sea ice, precipitation at high latitudes is increased by $30-50 \%$. Thus, with warmer temperatures at high latitudes during the last interglacial, it may also be possible to have greater precipitation from surrounding oceans via sea ice reduction.

Four independent AGCM reconstructions indicate that summer warming of about $3-4{ }^{\circ} \mathrm{C}$ could have occurred in interior Alaska during the last interglacial period, driven by the higher summer insolation at $\sim 126 \mathrm{ka}$ (Kutzbach et al., 1991; Harrison et al., 1991, 1995; de Noblet et al., 1996; Montoya et al., 1998). The presence of boreal forest in interior Alaska and Yukon during the last interglacial does not provide a definitive test of this hypothesis, although its presence permits such a reconstruction. However, the distribution of last interglacial boreal forest beyond its present limits on the Seward Peninsula indicates summer warming of at least $1-2^{\circ} \mathrm{C}$. The pollen evidence for boreal forest on St. Lawrence 


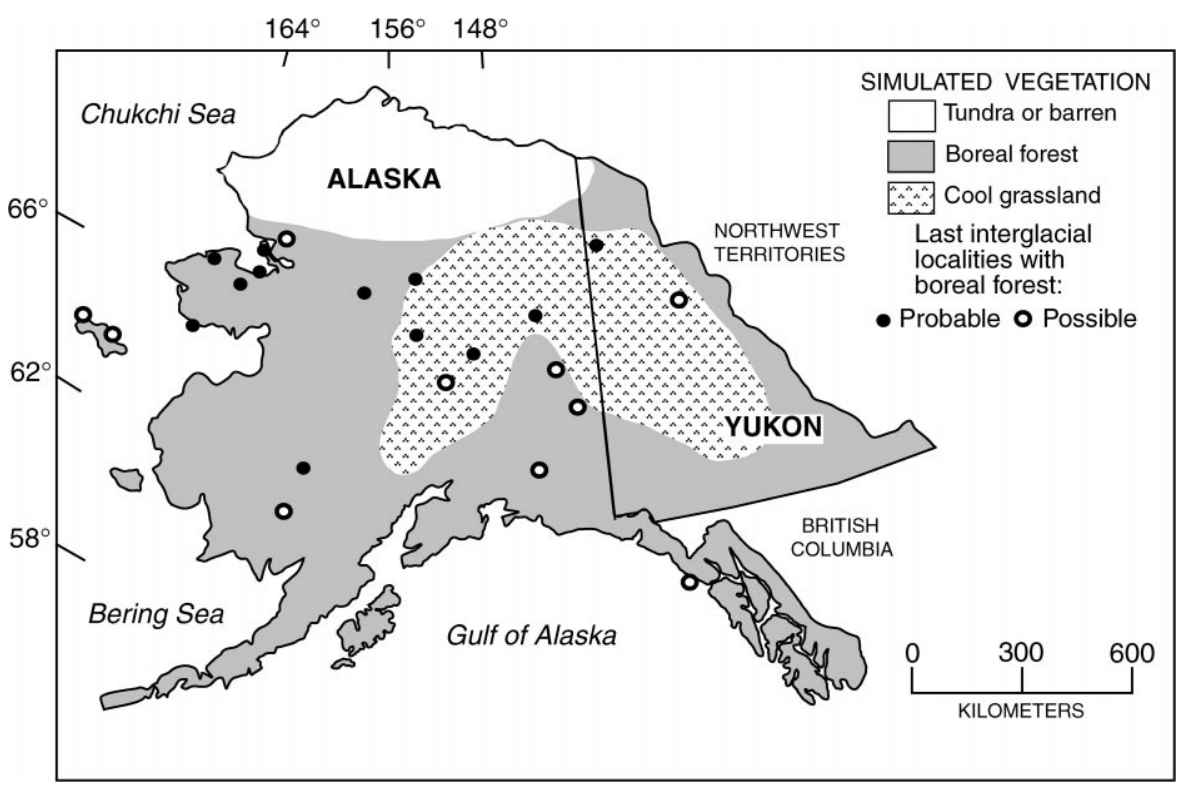

Fig. 16. Map of simulated vegetation in Alaska and Yukon during the peak of the last interglacial period at $\sim 126,000 \mathrm{yr}$ BP as modeled by Harrison et al. (1995) and plots of probable and possible last interglacial localities with boreal forest indicators (same as those shown in Fig. 15).

Island, if correctly assigned to the last interglaciation, requires a warming of about $3-5^{\circ} \mathrm{C}$ during summer (cf. Figs. 1 and 15). The AGCM results of Harrison et al. (1995) also indicate that this summer warming indirectly resulted in warmer winters in Alaska, even though winter insolation would have been lower at this time. This unexpected result derives from a simulation of less extensive Arctic Ocean sea ice, in turn derived from delayed sea ice formation in the fall, and earlier sea ice melting in the spring. Montoya et al. (1998) also simulated a decrease in Arctic sea ice during the last-interglacial, although not as much as that produced by the model of Harrison et al. (1995). Faunal data from Pelukian shorelines studied by Brigham-Grette and Hopkins (1995) are in good agreement with a simulation of reduced sea ice, as discussed above.

A major difference between the AGCM simulation of Harrison et al. (1995) with its linked biome simulation and our compilation of last interglacial localities is the extent of boreal forest in the interior of Alaska and Yukon. The AGCM results, despite the diminished sea ice extent, do not indicate increased precipitation in Alaska during the last interglacial. In fact, the model indicates a net moisture deficit, and the linked biome model produces a cool steppe in much of interior Alaska and Yukon (Fig. 16). The compilation of boreal forest localities presented here disagrees with the simulation of a cool steppe, and in particular the abundance of Polypodiaceae spores at Eva Creek and Birch Creek indicates that precipitation must have been higher than the present during the last interglacial. It is interesting to note that
Lozhkin and Anderson (1995) report an expanded boreal forest in northeast Siberia during the last interglacial, based on paleobotanical data, with both increased summer temperatures and slightly increased precipitation. The model of Harrison et al. (1995) also shows an expanded boreal forest in northeast Siberia during the last interglacial, in agreement with the data of Lozhkin and Anderson (1995), but also produced a moisture decrease compared to present. The comparison of model results for both Alaska and Siberia suggests that the AGCM of Harrison et al. (1995) is better at simulating temperature than precipitation.

\section{Conclusions}

(1) Stratigraphic studies at Eva Creek near Fairbanks indicate a complex last interglacial record wherein periods of loess deposition alternated with periods of soil formation, when loess deposition rates were lower. The Eva Forest Bed appears to have formed after the deposition of loess containing the Sheep Creek tephra ( $\sim 190 \mathrm{ka}$ ), perhaps partly overlapping in time with deposition of the Old Crow tephra $(\sim 160$ to $\sim 120 \mathrm{ka}$ ), and before deposition of the Dome tephra. Spruce wood fragments from this bed also have radiocarbon ages beyond the range of the method; we therefore correlate the forest bed with the peak of the last interglacial period, in agreement with Péwé et al. (1997).

(2) Pollen, macrofossil, and paleosol data from the Eva Forest Bed indicate that boreal forest was the dominant 
vegetation near Fairbanks during the peak of the last interglacial period, also in agreement with Péwé et al. (1997). New fossil spore and paleosol data indicate, however, that precipitation may have been greater than present at this time. The period of boreal forest growth may have been preceeded by cold, dry conditions with tundra vegetation of the penultimate glacial period. These dramatic changes in vegetation probably reflect the widely varying insolation at high latitudes during the past $200 \mathrm{ka}$.

(3) A new compilation of last interglacial localities indicates that boreal forest was extensive over interior Alaska and Yukon Territory. Boreal forest also extended beyond its present range onto the Seward and Baldwin Peninsulas, may have reached St. Lawrence Island, and probably extended to higher elevations now occupied by tundra in the interior. Under such implied warm conditions, it is possible that boreal forest spread to areas north of the Brooks Range as well.

(4) Comparison of last interglacial pollen and macrofossil data with atmospheric general circulation model (AGCM) results shows both agreement and disagreement. Model results of warmer-than-present summers and less extensive sea ice are in agreement with fossil data. However, numerous and widespread localities with boreal forest records are in conflict with model reconstructions of an extensive cool steppe in interior Alaska and much of Yukon Territory.

\section{Acknowledgements}

This study was supported by the Earth Surface Dynamics Program of the US Geological Survey (Muhs and Ager), and the Office of Polar Programs of the National Science Foundation (Begét), and is a contribution to the LITE (last interglacial: Timing and Environment) Project of the US Geological Survey. We thank Mike and Walt Wigger for generous access to the Eva Creek locality, and their continued encouragement of our studies there. Sharon VanLoenen (US Geological Survey) prepared the pollen samples, and Josh Been (US Geological Survey) processed soil and sediment samples and compiled the July temperature map. We thank Thomas W. Stafford, Jr. for three of the radiocarbon ages reported here and Elisabeth Wheeler (North Carolina State University) and Harry Alden (US Forest Products Laboratory) for identifying the wood specimens. We appreciate stimulating conversations with Mary Edwards, Troy Péwé, Scott Elias, Art Bettis, Shari Preece, Tom Hamilton and Nancy Bigelow. We also thank John Matthews for sharing his field notes from Eva Creek. Paul Carrara (US Geological Survey) and Vance Holliday (University of Wisconsin) read an earlier version of the paper and made helpful suggestions for its improvement.

\section{References}

Abbott, M.B., Stafford Jr., T.W., 1996. Radiocarbon geochemistry of modern and ancient Arctic lake systems, Baffin Island, Canada. Quaternary Research 45, 300-311.

Ager, T.A., 1975. Late Quaternary environmental history of the Tanana Valley, Alaska. Institute for Polar Studies Report 54, Ohio State University, $117 \mathrm{pp}$.

Ager, T.A., 1982. Vegetational history of western Alaska during the Wisconsin glacial interval and the Holocene. In: Hopkins, D.M., Matthews Jr., J.V., Schweger, C.E., Young, S.B. (Eds.), Paleoecology of Beringia. Academic Press, New York, pp. 75-93.

Ager, T.A., 1983. Holocene vegetational history of Alaska. In: Wright Jr., H.E. (Ed.), Late Quaternary Environments of the United States, The Holocene, Vol. 2. University of Minnesota Press, Minneapolis, pp. $128-141$.

Ager, T.A., 1989. History of late Pleistocene and Holocene vegetation in the Copper River Basin, south-central Alaska. U.S. Geological Survey Circular No. 1026, pp. 89-92.

Ager, T.A., Brubaker, L., 1985. Quaternary palynology and vegetational history of Alaska. In: Bryant Jr., V.M., Holloway, R.G. (Eds.), Pollen Records of Late-Quaternary North American Sediments. American Association of Stratigraphic Palynologists Foundation, Dallas, TX, pp. 353-383.

Allison, L.E., 1965. Organic carbon. In: Black, C.A. (Ed.), Methods of Soil Analysis. American Society of Agronomy, Madison, Wisconsin, pp. 1367-1378.

Anderson, P.M., Lozhkin, A.V., Eisner, W.R., Kozhevnikova, M.V., Hopkins, D.M., Brubaker, L.B., Colinvaux, P.A., 1994. Two late Quaternary pollen records from south-central Alaska. Géographie physique et Quaternaire 48, 131-143.

Barnola, J.M., Pimienta, P., Raynaud, D., Korotkevich, Y.S., 1991. $\mathrm{CO}_{2}$-climate relationship as deduced from the Vostok ice core: a re-examination based on new measurements and on a re-evaluation of the air dating. Tellus 43B, 83-90.

Begét, J.E., 1988. Tephras and sedimentology of frozen loess. In: Senneset, K. (Ed.), Fifth International Permafrost Conference Proceedings, Vol. I. Tapir, Trondheim, pp. 672-677.

Begét, J.E., 1990. Middle Wisconsin climate fluctuations recorded in central Alaskan loess. Géographie Physique et Quaternaire 44, 3-13.

Begét, J.E., 1996. Tephrochronology and paleoclimatology of the lastinterglacial-glacial cycle recorded in Alaskan loess deposits. Quaternary International 34-36, 121-126.

Begét, J.E., Edwards, M.E., Hopkins, D., Keskinen, M., Kukla, G., 1991. Old Crow tephra found at the Palisades of the Yukon, Alaska. Quaternary Research 35, 291-297.

Berger, A., Loutre, M.F., 1991. Insolation values for the climate of the last 10 million years. Quaternary Science Reviews 10, 297-317.

Berger, G.W., Péwé, T.L., Westgate, J.A., Preece, S.J., 1996. Age of Sheep Creek tephra (Pleistocene) in central Alaska from thermoluminescence dating of bracketing loess. Quaternary Research 45, 263-270.

Berger, G.W., Pillans, B.J., Palmer, A.S., 1994. Test of thermoluminescence dating of loess from New Zealand and Alaska. Quaternary Science Reviews 13, 309-333.

Brigham-Grette, J., Hopkins, D.M., 1995. Emergent marine record and paleoclimate of the last interglaciation along the northwest Alaskan coast. Quaternary Research 43, 159-173.

Bryson, R.A., 1966. Air masses, streamlines and the boreal forest. Geographical Bulletin 8, 228-269.

Bryson, R.A., Hare, F.K., 1974. The climates of North America. In: Bryson, R.A., Hare, F.K. (Eds.), Climates of North America, World Survey of Climatology, Vol. 11. Elsevier, Amsterdam, pp. 1-47. 
Carter, L.D., Ager, T.A., 1989. Late Pleistocene spruce (Picea) in northern interior basins of Alaska and the Yukon: evidence from marine deposits in northern Alaska. U.S. Geological Survey Circular No. 1026, pp. 11-14.

Chen, J.H., Curran, H.A., White, B., Wasserburg, G.J., 1991. Precise chronology of the last interglacial period: ${ }^{234} \mathrm{U}^{230} \mathrm{Th}$ data from fossil coral reefs in the Bahamas. Geological Society of America Bulletin 103, 82-97.

Colinvaux, P.A., 1964. The environment of the Bering Land Bridge. Ecological Monographs 34, 297-329.

Colinvaux, P.A., 1967. A long pollen record from St. Lawrence Island, Bering Sea (Alaska). Palaeogeography, Palaeoclimatology, Palaeoecology 3, 29-48.

Collins, L.B., Zhu, Z.R., Wyrwoll, K.-H., Hatcher, B.G., Playford, P.E., Chen, J.H., Eisenhauer, A., Wasserburg, G.J., 1993. Late Quaternary evolution of coral reefs on a cool-water carbonate margin: The Abrolhos carbonate platforms, southwest Australia. Marine Geology $110,203-212$.

Crowley, T.J., Yip, K-J.J., Baum, S.K., 1994. Effect of altered Arctic sea ice and Greenland ice sheet cover on the climate of the GENESIS general circulation model. Global and Planetary Change 9, 275-288.

de Noblet, N., Braconnot, P., Joussaume, S., Masson, V., 1996. Sensitivity of simulated Asian and African summer monsoons to orbitally induced variations in insolation 126, 115 and $6 \mathrm{kBP}$. Climate Dynamics 12, 589-603.

Doher, L.I., 1980. Palynomorph preparation procedures currently used in the paleontology and stratigraphy laboratories, U.S. Geological Survey. U.S. Geological Survey Circular No. 830, 29 pp.

Edwards, M.E., Armbruster, W.S., 1989. A tundra-steppe transition on Kathul Mountain, Alaska, U.S.A. Arctic and Alpine Research 21, 296-304.

Edwards, M.E., McDowell, P.F., 1991. Interglacial deposits at Birch Creek, northeast interior Alaska. Quaternary Research 35, 41-52.

Elias, S.A., Short, S.K., 1992. Paleoecology of an interglacial peat deposit, Nuyakuk, southwestern Alaska, U.S.A. Géographie Physique et Quaternaire 46, 85-96.

Elias, S.A., Short, S.K., Waythomas, C.F., 1996. Late Quaternary environments, Denali National Park and Preserve, Alaska. Arctic 49, 292-305.

Fernald, A.T., 1965. Glaciation in the Nabesna River area, upper Tanana River valley, Alaska. U. S. Geological Survey Professional Paper 525-C, C120-C123.

Guthrie, R.D., 1968. Paleoecology of a late Pleistocene small mammal community from interior Alaska. Arctic 21, 223-244.

Guthrie, R.D., 1990. Frozen Fauna of the Mammoth Steppe: The Story of Blue Babe. University of Chicago Press, Chicago, 323 pp.

Hamilton, T.D., Brigham-Grette, J., 1991. The last interglaciation in Alaska: Stratigraphy and paleoecology of potential sites. Quaternary International 10-12, 49-71.

Hamilton, T.D., Ager, T.A., Robinson, S.W., 1983. Late Holocene ice wedges near Fairbanks, Alaska, U.S.A: Environmental setting and history of growth. Arctic and Alpine Research 15, 157-168.

Hamilton, T.D., Craig, J.L., Sellmann, P.V., 1988. The Fox permafrost tunnel: A late Quaternary geologic record in central Alaska. Geological Society of America Bulletin 100, 948-969.

Hare, F.K., Hay, J.E., 1974. The climate of Canada and Alaska. In: Bryson, R.A., Hare, F.K. (Eds.), Climates of North America. World Survey of Climatology, Vol. 11. Elsevier, Amsterdam, pp. 49-192.

Harmon, R.S., Mitterer, R.M., Kriausakul, N., Land, L.S., Schwarcz, H.P., Garrett, P., Larson, G.J., Vacher, H.L., Rowe, M., 1983. U-series and amino-acid racemization geochronology of Bermuda:
Implications for eustatic sea-level fluctuation over the past 250,000 years. Palaeogeography, Palaeoclimatology, Palaeoecology 44, 41-70.

Harrison, S.P., Kutzbach, J.E., Behling, P., 1991. General circulation models, palaeoclimatic data and last interglacial climates. Quaternary International 10-12, 231-242.

Harrison, S.P., Kutzbach, J.E., Prentice, I.C., Behling, P.J., Sykes, M.T., 1995. The response of northern hemisphere extratropical climate and vegetation to orbitally induced changes in insolation during the last interglaciation. Quaternary Research 43, 174-184.

Heusser, C.J., 1960. Late Pleistocene environments of North Pacific North America. American Geographical Society Special Publication No. 35, 308 pp.

Heusser, C.J., 1983. Holocene vegetation history of the Prince William Sound region, south-central Alaska. Quaternary Research 19, $337-355$.

Höfle, C., Ping, C.-L., 1996. Properties and soil development of latePleistocene paleosols from Seward Peninsula, northwest Alaska. Geoderma 71, 219-243.

Hogg, E.H., 1994. Climate and the southern limit of the western Canadian boreal forest. Canadian Journal of Forest Research 24, $1835-1845$.

Hopkins, D.M., 1959. Some characteristics of the climate in forest and tundra regions in Alaska. Arctic 12, 215-220.

Hu, F.S., Brubaker, L.B., Anderson, P.M., 1993. A 12000-yr record of vegetation change and soil development from Wien Lake, central Alaska. Canadian Journal of Botany 71, 1133-1142.

Hultén, E., 1968. Flora of Alaska and Neighboring Territories. Stanford University Press, Stanford, Palo Alto.

Jenny, H., 1980. The Soil Resource: Origin and Behavior. Springer, New York.

Jouzel, J., Barkov, N.I., Barnola, J.M., Bender, M., Chappellaz, J., Genthon, C., Kotlyakov, V.M., Lipenkov, V., Lorius, C., Petit, J.R., Raynaud, D., Raisbeck, G., Ritz, C., Sowers, T., Stievenard, M., Yiou, F., Yiou, P., 1993. Extending the Vostok ice-core record of paleoclimate to the penultimate glacial period. Nature 364 , 407-412.

King, J.E., Saunders, J.J., 1986. Geochelone in Illinois and the IllinoianSangamonian vegetation of the type region. Quaternary Research $25,89-99$.

Kutzbach, J.E., Gallimore, R.G., Guetter, P.J., 1991. Sensitivity experiments on the effect of orbitally-caused insolation changes on the interglacial climate of high northern latitudes. Quaternary International 10-12, 223-229.

Larsen, J.A., 1989. The Northern Forest Border in Canada and Alaska. Springer, New York, 255pp.

Laxton, N.F., Burn, C.R., Smith, C.A.S., 1996. Productivity of loessal grasslands in the Kluane Lake region, Yukon Territory, and the Beringian Production Paradox. Arctic 49, 129-140.

LIGA Members, 1991. Report of the 1st discussion group: the last interglacial in high latitudes of the northern hemisphere: terrestrial and marine evidence. Quaternary International 10-12, 9-28.

Lorius, C., Jouzel, J., Ritz, C., Merlivat, L., Barkov, N.I., Korotkevich, Y.S., Kotlyakov, V.M., 1985. A 150,000-year climatic record from Antarctic ice. Nature 316, 591-596.

Lorius, C., Jouzel, J., Raynaud, D., Hansen, J., Le Treut, H., 1990. The ice-core record: climate sensitivity and future greenhouse warming. Nature 347, 139-145.

Lozhkin, A.V., Anderson, P.M., 1995. The last interglaciation in northeast Siberia. Quaternary Research 43, 147-158.

Maeda, Y., 1985. Pollen analysis of the drilling cores in St. Lawrence Island. In: Nakao, K. (Ed.), Hydrological Regime and Climatic Changes in the Arctic Circle. Laboratory of Hydrology, Department of Geophysics. Hokkaido University, Japan, pp. $34-36$. 
Mann, D.H., 1986. Wisconsin and Holocene glaciation of southeast Alaska. In: Hamilton, T.D., Reed, K.M., Thorson, R.M. (Eds.), Glaciation in Alaska-The Geologic Record. Alaska Geological Society, Anchoraye, Alaska, pp. 237-265.

Martinson, D.G., Pisias, N.G., Hays, J.D., Imbrie, J., Moore Jr., T.C., Shackleton, N.J., 1987. Age dating and the orbital theory of the ice ages: Development of a high-resolution 0 to 300,000-year chronostratigraphy. Quaternary Research 27, 1-29.

Matthews Jr., J.V., 1970. Quaternary environmental history of interior Alaska: pollen samples from organic colluvium and peats. Arctic and Alpine Research 2, 241-251.

Matthews Jr, J.V., Schweger, C.E., Janssens, J.A., 1990. The last (KoyYukon) interglaciation in the northern Yukon: evidence from Unit 4 at Ch'ijee's Bluff, Bluefish Basin. Géographie Physique et Quaternaire 44, 341-362

McCulloch, D.S., Taylor, D.W., Rubin, M., 1965. Stratigraphy, nonmarine mollusks, and radiometric dates from Quaternary deposits in the Kotzebue sound area, western Alaska. Journal of Geology 73, 442-453.

Montoya, M., Crowley, T.J., von Storch, H., 1998. Temperatures at the last interglacial simulated by a coupled ocean-atmosphere climate model. Paleoceanography 13, 170-177.

Muhs, D.R., Szabo, B.J., 1994. New uranium-series ages of the Waimanalo Limestone, Oahu, Hawaii: implications for sea level during the last interglacial period. Marine Geology 118, 315-326.

Muhs, D.R., Kennedy, G.L., Rockwell, T.K., 1994. Uranium-series ages of marine terrace corals from the Pacific coast of North America and implications for last interglacial sea level history. Quaternary Research 42, 72-87.

Muhs, D.R., Ager, T.A., Been, J.M., Rosenbaum, J.G., Reynolds, R.L., 2000. An evaluation of methods for identifying and interpreting buried soils in Late Quaternary loess in Alaska. U.S. Geological Survey Professional Paper 1615, pp 127-146.

Muhs, D.R., Ager, T., Stafford Jr., T.W., Pavich, M., Begét, J.E, McGeehin, J.P., 1997. The last interglacial-glacial cycle in late Quaternary loess, central interior Alaska. In: Elias, S.A., BrighamGrette, J. (Eds.), Program and Abstracts, Beringian Paleoenvironments Workshop. Florissant, Colorado, pp. 109-112.

Naeser, N., Westgate, J.A., Hughes, O.L., Péwé, T.L., 1982. Fission-track ages of late Cenozoic distal tephra beds in the Yukon Territory and Alaska. Canadian Journal of Earth Sciences 19, 2167-2178.

National Atlas Information Service and Petawawa National Forestry Institute, 1993. Canada: vegetation cover. The National Atlas of Canada, 5th Edition, Sheet 7.1. Scale: 1: 7,500,000.

Peteet, D.M., 1986. Modern pollen rain and vegetational history of the Malaspina Glacier District, Alaska. Quaternary Research 25, 100-120.

Péwé, T.L., 1975a. Quaternary geology of Alaska. U.S. Geological Survey Professional Paper No. 835, 145 pp.

Péwé, T.L., 1975b. Quaternary stratigraphic nomenclature in unglaciated central Alaska. U.S. Geological Survey Professional Paper No. 862, 32 pp.

Péwé, T.L., Wahrhaftig, C., Weber, F.R., 1966. Geologic map of the Fairbanks quadrangle, Alaska. U.S. Geological Survey Miscellaneous Investigations Map I-455, scale 1:250,000.

Péwé, T.L., Berger, G.W., Westgate, J.A., Brown, P.M., Leavitt, S.W., 1997. Eva Interglaciation Forest Bed, Unglaciated East-Central Alaska: Global Warming 125,000 Years Ago. Geological Society of America Special Paper No. 319, 54 pp.

Preece, S.J., Westgate, J.A., Gorton, M.P., 1992. Compositional variation and provenance of late Cenozoic distal tephra beds, Fairbanks area, Alaska. Quaternary International 13/14, 97-101.

Preece, S.J., Westgate, J.A., Stemper, B.A., Péwé, T.L., 1999. Tephrochronology of late cenozoic loess at fairbanks, central Alaska. Geological Society of America Bulletin 111, 71-90.
Reger, R.D., Pinney, D.S., Burke, R.M., Wiltse, M.A., 1996. Catalog and initial analyses of geologic data related to middle to late Quaternary deposits, Cook Inlet region, Alaska. State of Alaska Division of Geological and Geophysical Surveys Report of Investigations 95-6, $188 \mathrm{pp}$.

Rieger, S., Schoephorster, D.B., Furbush, C.E., 1979. Exploratory Soil Survey of Alaska. U.S. Government Printing Office (Soil Conservation Service), Washington, $213 \mathrm{pp}$.

Ritchie, J.C., 1987. Postglacial Vegetation of Canada. Cambridge University Press, Cambridge, 178 pp.

Schwarz, A.G., Wein, R.W., 1997. Threatened dry grasslands in the continental boreal forest of Wood Buffalo National Park. Canadian Journal of Botany 75, 1363-1370.

Schweger, C.E., Matthews Jr., J.V., 1991. The last (Koy-Yukon) interglaciation in the Yukon: Comparisons with Holocene and interstadial pollen records. Quaternary International 10-12, $85-94$.

Seidenkrantz, M.-S., Bornmalm, L., Johnsen, S.J., Knudsen, K.L., Kuijpers, A., Lauritzen, S.-E., Leroy, S.A.G., Mergeai, I., Schweger, C., Van Vliet-Lanoe, B., 1996. Two-step deglaciation at the oxygen isotope stage 6/5e transition: The Zeifen-Kattegat climate oscillation. Quaternary Science Reviews 16, 63-75.

Shackleton, J., 1982. Environmental histories from Whitefish and Imuruk Lakes, Seward Peninsula, Alaska. Ohio State University Institute of Polar Studies Report No. 76, 50 pp.

Szabo, B.J., Ludwig, K.R., Muhs, D.R., Simmons, K.R., 1994. Thorium-230 ages of corals and duration of the last interglacial sea-level high stand on Oahu, Hawaii. Science 266, 93-96.

Thornthwaite, C.W., Mather, J.R., 1957. Instructions and tables for computing potential evapotranspiration and the water balance. Publications in Climatology (Laboratory of Climatology, Centerton, NJ) 10, 185-311.

Van Cleve, K., Dyrness, C.T., Viereck, L.A., Fox, J., Chapin III, F.S., Oechel, W., 1983. Taiga ecosystems of interior Alaska. BioScience 33, 39-44.

Van Cleve, K., Chapin III, F.S., Dyrness, C.T., Viereck, L.A., 1991. Element cycling in taiga forests: state-factor control. BioScience 41, $78-88$.

Van Cleve, K., Dyrness, C.T., Marion, G.M., Erickson, R., 1993. Control of soil development on the Tanana River floodplain, interior Alaska. Canadian Journal of Forest Research 23, 941-955.

Viereck, L.A., Little Jr, E.L., 1972. Alaska trees and shrubs. U.S. Department of Agriculture Handbook, Vol. 410, 265 pp.

Waythomas, C.F., Lea, P.D., Walter, R.C., 1993. Stratigraphic context of Old Crow tephra, Holitna Lowland, interior southwest Alaska. Quaternary Research 40, 20-29.

Weber, F.R., Ager, T.A., 1984. Glacial-lake deposits in the Mount Harper area, Yukon-Tanana Upland. U. S. Geological Survey Circular $868,68-70$

Westgate, J., 1988. Isothermal plateau fission-track age of the late Pleistocene Old Crow tephra, Alaska. Geophysical Research Letters $15,376-379$.

Westgate, J., 1989. Isothermal plateau fission-track ages of hydrated glass shards from silicic tephra beds. Earth and Planetary Science Letters 95, 226-234.

Westgate, J.A., Hamilton, T.D., Gorton, M.P., 1983. Old Crow tephra: A new late Pleistocene stratigraphic marker across north-central Alaska and western Yukon Territory. Quaternary Research 19, $38-54$.

Westgate, J.A., Stemper, B.A., Péwé, T.L., 1990. A 3 m.y. record of Pliocene-Pleistocene loess in interior Alaska. Geology 18, $858-861$.

Westgate, J.A., Walter, R.C., Pearce, G.W., Gorton, M.P., 1985. Distribution, stratigraphy, petrochemistry, and palaeomagnetism of the late Pleistocene Old Crow tephra in Alaska and the Yukon. Canadian Journal of Earth Sciences 22, 893-906. 
Winograd, I.J., Coplen, T.B., Landwehr, J.M., Riggs, A.C., Ludwig, K.R., Szabo, B.J., Kolesar, P.T., Revesz, K.M., 1992. Continuous 500,000-year climate record from vein calcite in Devils Hole, Nevada. Science 258, 255-260.

Woillard, G.M., 1978. Grand Pile Peat Bog: a continuous pollen record for the last 140,000 years. Quaternary Research 9, 1-21.
Zagwijn, W.H., 1996. An analysis of Eemian climate in western and central Europe. Quaternary Science Reviews 15, 451-469.

Zhu, H., Baker, R.G., 1995. Vegetation and climate of the last glacialinterglacial cycle in southern Illinois, USA. Journal of Paleolimnology $14,337-354$. 